\title{
Molecular Mechanisms during Hepatitis B Infection and the Effects of the Virus Variability
}

\author{
Marina Campos-Valdez ${ }^{1}$, Hugo C. Monroy-Ramírez ${ }^{1}$, Juan Armendáriz-Borunda ${ }^{1,2}$ (D) \\ and Laura V. Sánchez-Orozco ${ }^{1, *}$ \\ 1 Centro Universitario de Ciencias de la Salud, Departamento de Biología Molecular y Genómica, \\ Instituto de Biología Molecular en Medicina, Universidad de Guadalajara, Guadalajara 44340, Jalisco, \\ México; campos.ibt@gmail.com (M.C.-V.); hugo.monroyram@academicos.udg.mx (H.C.M.-R.); \\ armdbo@gmail.com (J.A.-B.) \\ 2 Escuela de Medicina y Ciencias de la Salud, Tecnológico de Monterrey, Campus Guadalajara, \\ Zapopan 45201, Jalisco, México \\ * Correspondence: laura.sorozco@academicos.udg.mx; Tel.: +52-33-3954-5677
}

Citation: Campos-Valdez, M.;

Monroy-Ramírez, H.C.;

Armendáriz-Borunda, J.;

Sánchez-Orozco, L.V. Molecular Mechanisms during Hepatitis B Infection and the Effects of the Virus Variability. Viruses 2021, 13, 1167.

https://doi.org/10.3390/v13061167

Academic Editor: Kei Fujiwara

Received: 1 May 2021

Accepted: 11 June 2021

Published: 18 June 2021

Publisher's Note: MDPI stays neutral with regard to jurisdictional claims in published maps and institutional affiliations.

\section{Copyright: (c) 2021 by the authors.} Licensee MDPI, Basel, Switzerland. This article is an open access article distributed under the terms and conditions of the Creative Commons Attribution (CC BY) license (https:// creativecommons.org/licenses/by/ $4.0 /)$.

\begin{abstract}
The immunopathogenesis and molecular mechanisms involved during a hepatitis B virus (HBV) infection have made the approaches for research complex, especially concerning the patients responses in the course of the early acute stage. The study of molecular bases involved in the viral clearance or persistence of the infection is complicated due to the difficulty to detect patients at the most adequate points of the disease, especially in the time lapse between the onset of the infection and the viral emergence. Despite this, there is valuable data obtained from animal and in vitro models, which have helped to clarify some aspects of the early immune response against HBV infection. The diversity of the HBV (genotypes and variants) has been proven to be associated not only with the development and outcome of the disease but also with the response to treatments. That is why factors involved in the virus evolution need to be considered while studying hepatitis B infection. This review brings together some of the published data to try to explain the immunological and molecular mechanisms involved in the different stages of the infection, clinical outcomes, viral persistence, and the impact of the variants of HBV in these processes.
\end{abstract}

Keywords: acute hepatitis B; chronic hepatitis B; immune pathogenesis; acute liver failure; HBV sensing; HBV variability; HBV interference

\section{Introduction}

HBV is a small hepatotropic DNA virus where an envelope is formed by a lipid bilayer with the small, middle, and large size surface antigens (S-HBsAg, M-HBsAg, and L-HBsAg) embedded as transmembrane proteins [1,2]. The envelope surrounds a nucleocapsidformed by 120 core proteins ( $\mathrm{HBcAg}$ ) dimers - that stores the viral genome and polymerase (HBVPol) [3,4] (Figure 1a).

The viral genome consists of a $3.2 \mathrm{~kb}$ relaxed circular DNA (rcDNA) molecule. It contains four open reading frames (ORFs) encoding for polymerase $(\mathrm{P})$, surface $(\mathrm{S})$, precore/core $(\mathrm{C})$, and $\mathrm{X}$ (Figures $1 \mathrm{~b}$ and 2 ) [5]. HBV replication and transcription are controlled by its regulatory elements, such as enhancers, promoters (S1, S2, pre-core, core, and X); and signals of encapsidation $(\varepsilon)$, polyadenylation, and replication (direct repeats 1 and 2, DR1 and DR2) [4].

An important trait of the viral genome is the overlap of its ORFs; around $52 \%$ of the nucleotides code for more than one viral protein. Deletions and non-synonymous mutations in overlapping regions impact the HBV genotypes evolution and the differentiation of the pre-S domain (key in the infection process) [6]. The evolution rate of HBV has been estimated at around $1.4 \times 10^{-4}-5.7 \times 10^{-5}$ substitutions per site per year [7], being the pre-S/S region the most heterogeneous of HBV genome [8]. 
a)

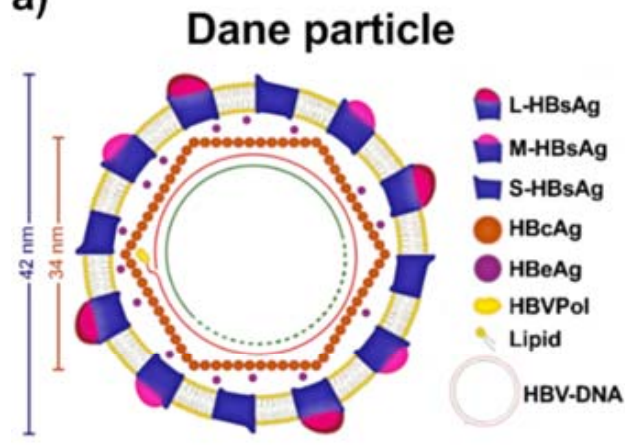

Subviral particles

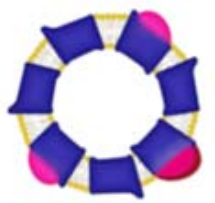

Sphere

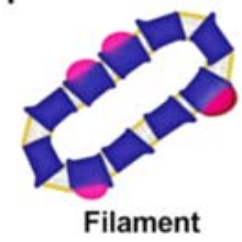

b)

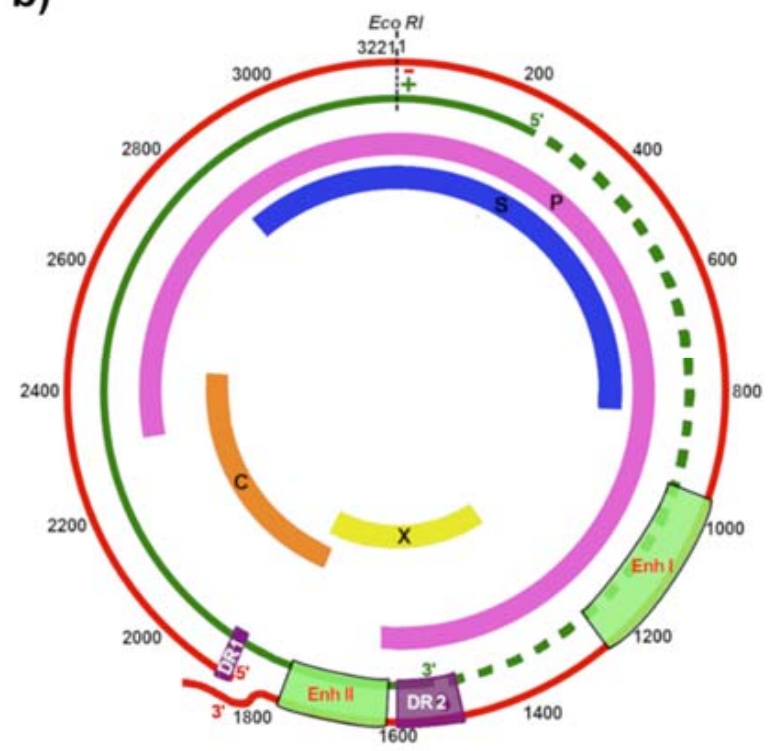

Figure 1. HBV (a) particle structures and (b) genome and ORFs. In red and green, the negative and positive strands (respectively) of HBV genome; colored boxes indicate the approximate location of the ORFs; green rectangles indicate enhancer regions and purple rectangles direct repeat regions. Abbreviations: HBV, hepatitis B virus; DR, direct repeat; Enh, enhancer; $\mathrm{P}$, polymerase; $\mathrm{S}$, surface; $\mathrm{C}$, core; $\mathrm{X}, \mathrm{X}$ protein gene.

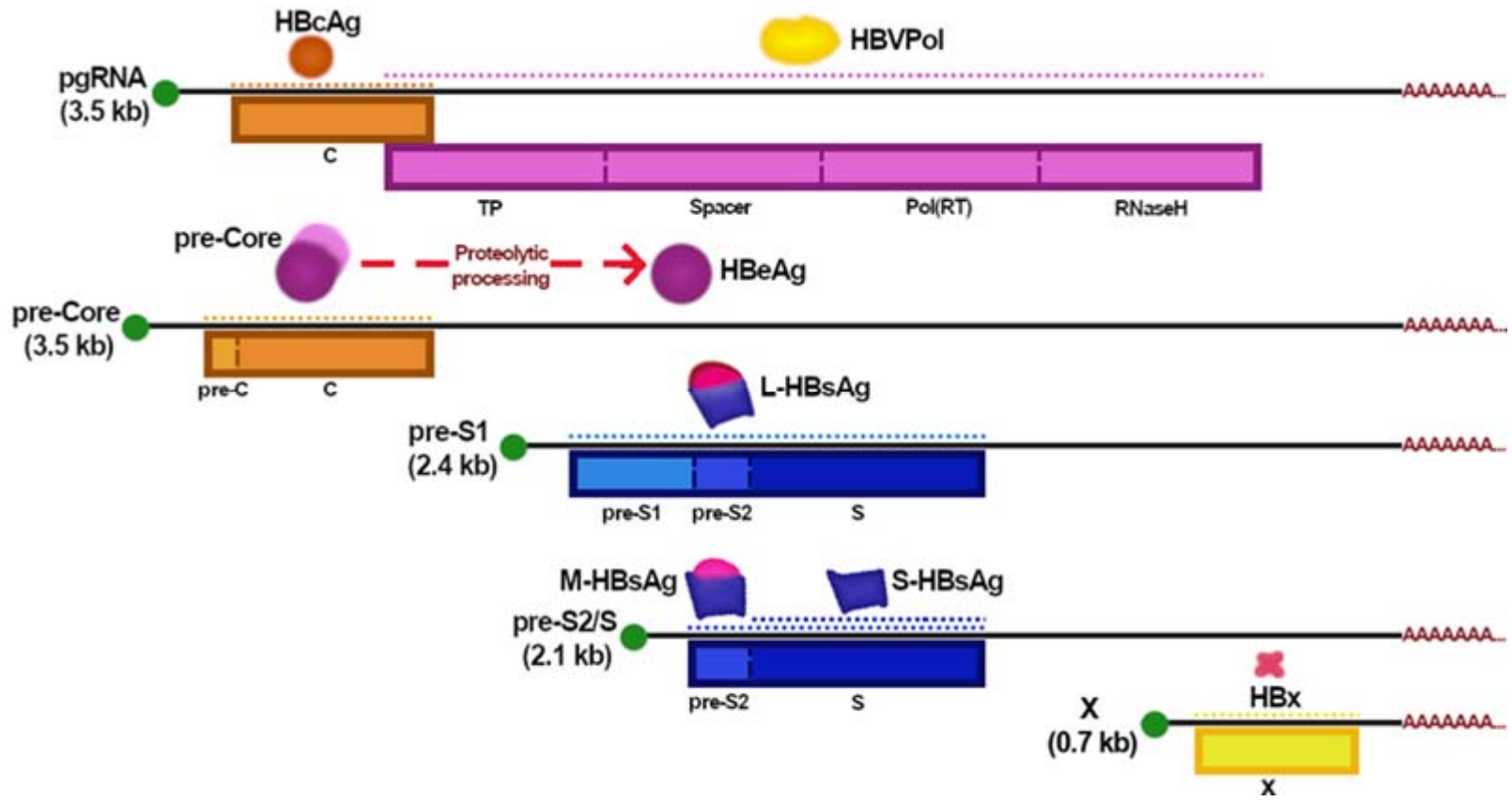

Figure 2. A representation of the HBV mRNAs and the translation of viral proteins. $5^{\prime}$-cap is shown as areen dot and polyA tail in red; the rectangles in colors represent the ORFs while the dotted lines represent the translated segments to produce the viral proteins. Abbreviations: kb, kilobase; pgRNA, pregenomic RNA; HBcAg, HBV core antigen; HBVPol, HBV polymerase; C, core; TP, terminal protein; Pol(RT), polymerase reverse transcriptase; HBeAg, HBV e antigen; S-, M-, and L-HBsAg; HBV small, middle, and large size surface antigens; HBX, HBV X protein.

The variability of the HBV genome is driven not only by viral fitness and the lack of corrective activity by the HBVPol, but mutants also result from their selection through pressure exerted by endogenous (host's immune pressure) and exogenous (antiviral therapy and vaccination) factors $[8,9]$. It has been found that there is a strong selection in the pre- 
S1 region, which overlaps with nucleotides encoding the spacer domain of the HBVPol, which is relatively adaptable to non-synonymous mutations. The accumulation of these variants provides flexibility for conformational structural changes and responds to immune selective pressure $[10,11]$.

\section{HBV Replicative Cycle}

The virus replicative cycle (Figure 3) starts with binding L-HBsAg with the sodium taurocholate contransporting polypeptide (NTCP) to mediate the entry of the viral particle into hepatocytes [12]. The virus is endocytosed and transported to the nucleus while the viral capsid is de-enveloped $[13,14]$. The viral genome seems to enter the nucleus through the nuclear pores and is repaired by host factors and transformed into the form of covalently closed circular DNA (cccDNA). This replication intermediate associates with host proteins to form a viral minichromosome that functions as a template for viral RNA transcription [15-17]. Five viral mRNAs are produced (Figure 2), including the pregenomic RNA (pgRNA), which is the main intermediate in the viral replication. pgRNA is exported to the cytosol where its $5^{\prime}$-end binds to the HBVPol and induces the packaging process $[4,18]$. Then, inside the nucleocapsid, the pgRNA is reverse transcribed by the viral polymerase into a new-rcDNA. Alternatively, a double-strand linear DNA (dsIDNA) is formed and plays an important role in the HBV-DNA integration into the host genome $[4,18]$. The mature capsids can either deliver the rcDNA into the nucleus, increasing the cccDNA content or binding to HBV surface proteins in the endoplasmic reticulum (ER) to be secreted as virions outside the hepatocytes [16].

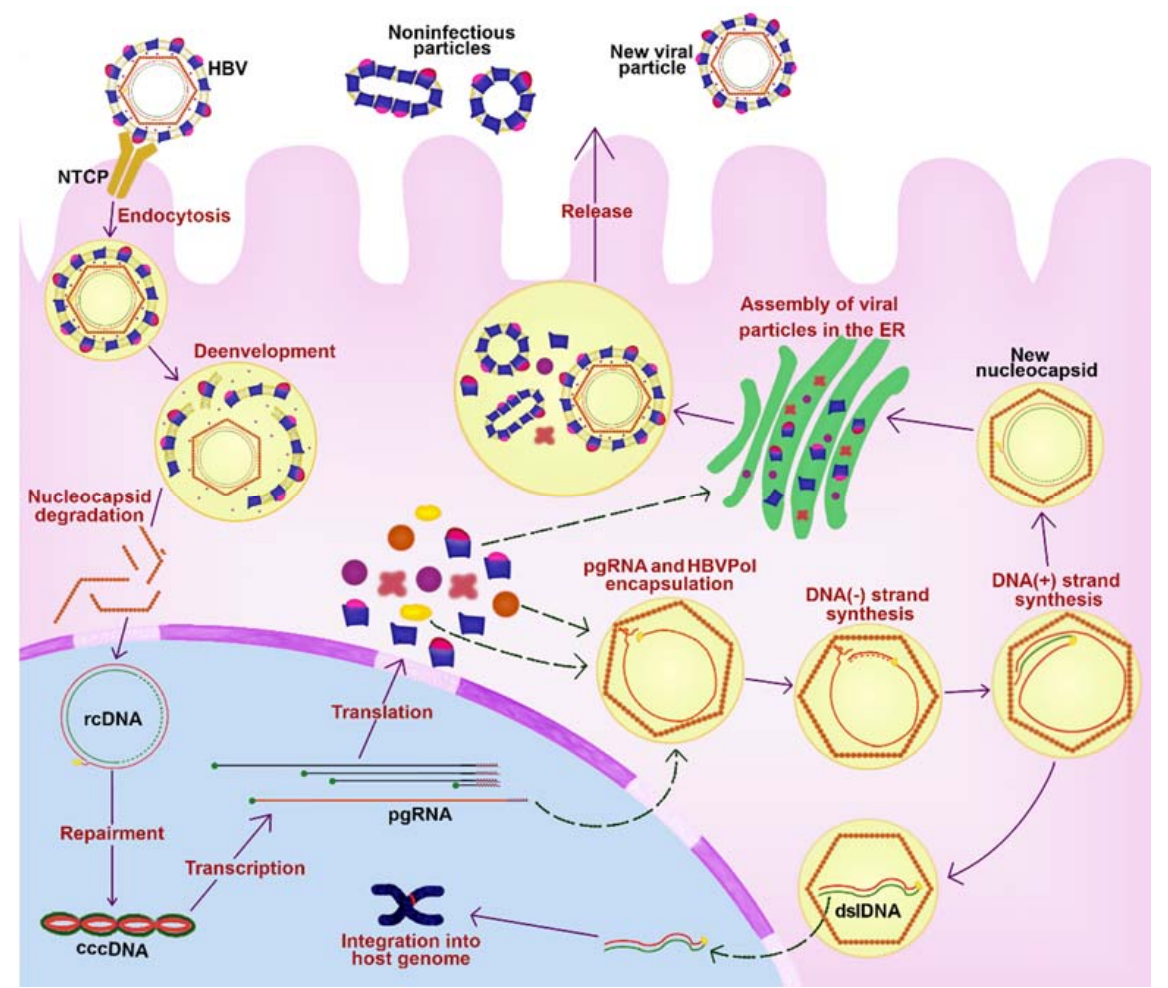

Figure 3. HBV replicative cycle. HBV undergoes endocytosis through the NTCP. Inside the cell, the rcDNA enters the nucleus, where it is repaired to form the cccDNA. The latter forms a viral minichromosome for the transcription of viral RNAs. The pgRNA binds to HBVPol in the cytosol to induce the packaging process that is followed by the synthesis of the HBV-DNA. The new viral particle is assembled in the ER and translocated to be secreted outside the hepatocytes as virions. Abbreviations: HBV, hepatitis B virus; NTCP, sodium taurocholate cotransporting polypeptide; rcDNA, relaxed circular DNA; cccDNA, covalently closed circular DNA; pgRNA, pregenomic RNA; ER, endoplasmic reticulum; HBVPol, HBV polymerase; dsIDNA, double-stranded linear DNA. 
HBV variants could emerge during the replicative cycle by different mechanisms, such as (a) cytosine deamination induced by host APOBEC (apolipoprotein B mRNA editing enzyme) enzymes, (b) errors incorporated during pgRNA transcription, (c) failure in the host DNA repair mechanisms, (d) error-prone activity of the HBVPol (during DNA polymerization dependent of either RNA or DNA), (e) generation of different HBV forms (such as HBV dslDNA and spliced forms that can produce novel fusion proteins), and (f) viral recombination [19].

\section{HBV Genotypes and Variants}

HBV has been classified into nine genotypes (A-I), one putative genotype (J), and at least 35 subtypes (Table 1) [5]. The virus genotypes and subgenotypes are differentiated by $>7.5 \%$ and $4-7.5 \%$ differences in all nucleotides of the viral genome, respectively. Subgenotypes are subdivided into clades which differ by $<4 \%$ [20]. Moreover, based on the HBsAg heterogeneity, nine serological subtypes (ayw1-ayw4, ayr, adw2, adw4, adwq, adr, and adrq-) have been identified. Moreover, there is a significant correlation between serological subtypes and genotypes: adw being associated with genotypes A, B, F, G, and H, adr with $\mathrm{C}$, and ayw with $\mathrm{D}$ and $\mathrm{E}$; however, many exceptions have been reported [21].

Table 1. HBV genotypes and their distinguishing features.

\begin{tabular}{|c|c|c|c|}
\hline Genotype & $\begin{array}{l}\text { Genome } \\
\text { Size (bp) }\end{array}$ & Subgenotypes & Distinguishing Features \\
\hline A & 3221 & $\begin{array}{c}\mathrm{A} 1, \mathrm{~A} 2, \mathrm{~A} 4 \text {, and } \\
\text { quasi-subgenotype A3 }\end{array}$ & $\begin{array}{l}6 \text { bp insertion at the } 3^{\prime} \text {-end of core gene (Insertion of aa } 153 \text { and } \\
154 \text { in } \mathrm{HBcAg} \text { ) } \\
\text { Unusual G1896A mutation } \\
\text { Common BCP mutations }\end{array}$ \\
\hline B & 3215 & $\begin{array}{c}\text { B1, B2, B4-B6, and } \\
\text { quasi-subgenotype B3 }\end{array}$ & $\begin{array}{l}\mathrm{B} 1 \text { and } \mathrm{B} 5 \text { are pure } \mathrm{HBV} / \mathrm{B} \text { strains } \\
\mathrm{B} 2, \mathrm{~B} 3 \text {, and } \mathrm{B} 4 \text { are recombinants with genotype } \mathrm{C} \text { in the core } \\
\text { region }\end{array}$ \\
\hline $\mathrm{C}$ & 3215 & $\mathrm{C} 1-\mathrm{C} 16$ & Common BCP mutations \\
\hline $\mathrm{D}$ & 3182 & D1-D6 & $\begin{array}{l}33 \text { bp deletion at the } 5^{\prime} \text {-end of pre-S1 region (Deletion of aa 1-11 } \\
\text { in pre-S1) }\end{array}$ \\
\hline $\mathrm{E}$ & 3212 & - & $\begin{array}{l}3 \text { bp deletion at } 5^{\prime} \text {-end of the pre-S1 region (Deletion of aa } 11 \text { in } \\
\text { pre-S1) }\end{array}$ \\
\hline $\mathrm{F}$ & 3215 & F1-F4 & $\begin{array}{l}\text { Unusual G1896A mutation } \\
36 \text { bp insertion at position } 190 \text { in the core ORF (Insertion of } 12 \\
\text { aa in } \mathrm{HBcAg} \text { ) }\end{array}$ \\
\hline G & 3248 & - & $\begin{array}{l}3 \text { bp deletion at the } 5^{\prime} \text {-end in the pre-S1 region (Deletion of aa } \\
11 \text { in pre-S1) } \\
\text { Stop codons at positions } 2 \text { and } 28 \text { (G1896A) of the pre-core ORF } \\
\text { render it unable to express HBeAg } \\
\text { Usually found in coinfection with other genotypes that express } \\
\text { HBeAg }\end{array}$ \\
\hline $\mathrm{H}$ & 3215 & - & Unusual G1896A mutation \\
\hline I & 3210 & I1 and I2 & $\begin{array}{l}\text { Evolved as a recombinant of genotypes A, C, and G } \\
\text { Single HBV isolate identified in an elderly Japanese patient } \\
\text { with HCC }\end{array}$ \\
\hline $\mathrm{J}$ & 3182 & & $\begin{array}{l}\text { Highly divergent from others human HBV strains } \\
\text { Likely a genotype C-gibbon Orthohepadnavirus recombinant } \\
\text { strains }\end{array}$ \\
\hline
\end{tabular}

Data was taken from Kramvis, 2014 [21], McNaughton et al., 2019 [5], and Schaefer, 2007 [22]. Abbreviations: HBV, hepatitis B virus; bp, base pair; aa, amino acids; G, guanine; A, adenine; T, thymine; BCP, basal core promoter; HCC, hepatocellular carcinoma.

Many studies describe the frequency of HBV mutations; a good example is a recent large-scale analysis of HBV genome sequences $(n=6479$, genotypes A-H) in which they report that immune escape mutations were present in $10.7 \%$ of the sequences (genotype B showing the highest rate). They also found that hepatocellular carcinoma (HCC) associated mutations were present in $33.7 \%$ of the sequences and that the overall frequencies of 
lamivudine-, telbivudine-, adefovir-, and entecavir-resistant mutants were $7.3 \%, 7.2 \%, 0.5 \%$, and $0.2 \%$, respectively, while only $0.05 \%$ showed reduced susceptibility to tenofovir [9].

In 2020, Velkov et al. published the results of an HBV nucleotide sequences analysis of the global occurrence of clinically relevant virus variants. They identified differences in the clinical manifestation of HBV infection between genotypes and their geographical locations [23].

\subsection{Clinical Relevance of HBV Diversity during Infection}

There is scientific information that compiles, summarizes, and analyzes what is known about HBV genotypes (epidemiology, clinical relevance, variants, and geographical distribution) [21,24-26]. Some of the most relevant data are:

(a) The association of genotype A with durable remission after HBeAg seroconversion. Those patients infected with genotypes A and B have higher rates of HBsAg seroclearance than genotypes D and C, respectively [27].

(b) Infection with genotype $\mathrm{A}$ is an independent risk factor for progression to chronic hepatitis $\mathrm{B}(\mathrm{CHB})$, and the treatment with nucleoside/nucleotide analogues (NAs) does not prevent progression to chronicity [28].

(c) Genotype C is more prone to cause CHB compared to genotype B [29].

(d) Genotype D appears to be more prevalent in patients with HBV-related acute liver failure [30].

(e) Genotype C and D are associated with a higher viral load compared to genotypes B and $A$, respectively. Infection with genotype $H$ is associated with a low viral load; nevertheless, it is difficult to elucidate their association with liver diseases since patients infected with this genotype usually have additional risk factors, such as alcohol consumption, co-infection with hepatitis $C$ virus, and obesity $[31,32]$.

\subsection{Drug-Resistant Variants}

NAs inhibit the activity of HBVPol by targeting its RT domain. The major downside of this therapy is the apparition of drug-resistant mutations due to long-term treatment. The development of drug resistance is caused by primary HBVPol (RT domain) mutations, which affect NAs recognition and binding, and therefore allowing HBV replication but with a reduced fitness compared to the wild-type HBV strain. These primary mutations usually go along with compensatory mutations that restore and improve the HBV fitness affected by primary mutations $[23,33]$. The major mutational patterns in NAs resistance are the RT domain mutations rtL180M/rtM204(I/V) (for lamivudine, entecavir, telbivudine, and clevudine) and rtA181V/rtN236T (for adefovir and tenofovir (TDF)) [34]. In a large-scale analysis, rtM204V/I and rtL180M were identified as the most abundant mutations known to cause resistance. Furthermore, mutation rtA194T (one of the few tenofovir resistance mutations [35]) was identified in several genotypes, albeit in very low numbers, except for genotype $\mathrm{H}[23]$.

It was recently observed that differential response to tenofovir (HBV rapid clearance or on-drug persistence) might be associated with the genetic variations across the whole HBV genome and may be specific for each genotype. Analysis of the inferred 3D structures showed no difference in the TDF recognition and binding by the RT-domain of HBVPol among intra-host HBV variants that rapidly decline or persist in the presence of TDF [36]. It is interesting that the mutation rtA194T in combination with HBeAg negative and pre-core or basal core promoter (BCP) mutants increase the replication capacity of the drug-resistant mutants and thereby restores the viral fitness in vitro. This would indicate that patients with HBeAg negative chronic infection may be at risk of developing drug resistance to TDF [35].

HBVPol RT domain region is affected by its overlap with the $S$ gene. A lower rate of synonymous substitution within this overlapping region has been reported; the most conserved RT regions were located within the YMDD motif and the N-terminal that are critical for RT functionality. These regions correspond to highly conserved HBsAg domains 
which are crucial for its secretion [37]. An analysis of the amino acid (aa) substitution rate in the overlapping region of the $S$ gene and the RT domain in patients with CHB reported that those with detectable aa substitution in either/both of RT/S sequences had significantly lower serum HBV-DNA and HBsAg levels compared to patients without detectable RT/S aa substitutions [38]. Another consequence of the RT/S overlap is that some drug-resistant mutations may even escape vaccine-induced anti-HBsAg antibodies [39].

The presence of resistant-to-NAs mutations has been extensively studied due to the importance of these types of drugs for HBV infection treatment. These mutants in naïvetreatment patients should be considered during the natural history of the infection for the patients' effective treatment selection.

\subsection{HBV-Related HCC}

Risk factors associated with HCC development over time are advanced age, male sex, elevated alanine aminotransferase (ALT) level, positive HBeAg, and high HBV-DNA levels [40]. In addition, numerous studies support the hypothesis that HBV genotypes diversity and variants may influence the risk of HCC development.

A report from India shows that a prevalence of $50 \%$ for genotype D and $25 \%$ for genotypes $A$ and $C$ each affects HBV-related HCC cases [41]. Before this, it was described that genotype $\mathrm{D}$ and mixed genotypes $(\mathrm{A}+\mathrm{D})$ infections have a higher risk of developing HCC compared to genotype A [42]. Moreover, subgenotype D1 might have a greater oncogenic potential compared to subgenotype D3 [43].

In Taiwanese and Japanese patients, the risk of HCC was higher in genotype C compared to genotype B and A [40,44-46]. In addition, BCP double mutation T1762/A1764 is more frequent in genotype C compared to genotype B increasing the risk for HCC [47]. In those patients infected with genotype B, non-cirrhotic HCC early onset is more common; whereas, genotype $\mathrm{C}$ is associated with cirrhotic HCC late-onset [48]. Nonetheless, chronically HBV-infected Japanese patients treated with NAs indicated that those infected with genotype $\mathrm{B}$ had a higher probability of HBsAg loss during treatment than those infected with genotype C [46]. While in Asia, genotypes B and C have been compared as the most prevalent in that region, a study in Alaska, where different genotypes are prevalent, a significant association between genotype $\mathrm{F}$ infection with the development of HCC was found, independent of the presence or absence of BCP mutations [49]. Besides BCP and pre-core mutations, viral variants within the $\mathrm{X}$ and pre-S1 region are also associated with the risk of HCC development. Failure in NAs treatment associated with HBV mutations allows the replicative state of HBV raising the viral load and, together with the previously mentioned mutations, increases the risk of HCC development [48]. Teng et al. demonstrated that the presence of deletions into the pre-S region is related to the risk or recurrence of HCC [50]. In Japan, a study performed with $40 \mathrm{HBV}$ genomes (95\% genotype C) obtained from HBsAg-positive HCC patients noticed that deletions and miss-sense mutations were frequent in the pre-S2 region. Furthermore, about $90 \%$ of the isolated HBV had double T1762/A1764 BCP mutation, which highlighted its relevance in HCC development [51]. Excessive HBsAg accumulation in the ER could be inducing the activation of unfolded protein response (UPR) and leading to ground glass hepatocytes (GGHs) [52]. GGHs have been reported as HBV-related HCC markers and represent precursor lesions. It has been demonstrated that pre-S deleted proteins may promote HCC development by activating oncogenic signaling pathways in hepatocytes [53-57]. Different types of GGHs contain specific pre-S mutations, type I harboring pre-S1 deletions and type II containing deletions over pre-S2 [58]. The ER stress induced by pre-S2 deletions causes DNA damage, centrosome overduplication, and genomic instability, and the presence of these mutants in sera frequently develops resistance to NAs [59]. Type II GGHs are more likely to be in cases of HCC and are associated with advanced fibrosis in CHB [60]. 


\section{Natural History of the HBV Infection}

In highly endemic areas, perinatal and horizontal transmission (especially from an infected to an uninfected child during the first 5 years of life) are the most common routes [61]. Infants born to mothers $\mathrm{HBsAg}$ and $\mathrm{HBeAg}$ positive are at a higher risk of acquiring HBV infection (transmission risk: $70-100 \%$ in Asia and $40 \%$ in Africa) than those born to $\mathrm{HBsAg}$ positive and HBeAg negative (5-30\% in Asia and $5 \%$ in Africa) [62]. HBV horizontal transmission is especially important in children because of the high risk of acquiring chronic asymptomatic infection. Children with $\mathrm{CHB}$ are more prone than adults to be HBeAg positive and to have a high viral load. Significant amounts of HBV-DNA have been found in body fluids (tears, saliva, sweat, and urine) of CHB carriers, including children [63-67]. Due to children's frequent close person-to-person contact between them, they are at a higher risk of infection [68]. In low-prevalence areas, HBV spreads through sexual contact and percutaneous (primarily injecting drug use) route; in this setting, the infection usually manifests as acute hepatitis [69]. At least $95 \%$ of immunocompetent adults with symptomatic acute hepatitis B (AHB) will recover spontaneously [70]. In total, $80-90 \%$ of those infected by vertical transmission develop CHB, while $30-50 \%$ and $<5 \%$ among those infected before being 6 years old and during adulthood, respectively, evolve to chronicity [61,70-72].

\subsection{Acute Hepatitis $B$}

The incubation period of AHB ranges from one to four months post-infection. Symptomatic AHB is primarily an adulthood disease, while two-thirds of the patients remain asymptomatic. The clinical presentation of HBV infection can be a serum-sickness-like illness characterized by fever, arthralgias, and rash, which may occur in the prodromal period. It is followed by constitutional symptoms, anorexia, nausea, jaundice, and right upper quadrant discomfort. Serum biochemical markers are characterized by elevated ALT activity and usually a mild elevation in bilirubin [69].

Acute liver failure (ALF) is the most serious complication of AHB; however, it happens in $<0.5 \%$ of patients. The ones at risk of this outcome are those infected with BCP and/or pre-core mutations, those coinfected with other hepatitis viruses, and/or those with underlying liver disease [69].

The resolution of infection is accompanied by anti-HBs seroconversion $\geq 10 \mathrm{IU} / \mathrm{mL}$ and viral clearance. Nonetheless, there are cases of hidden infection distinguished by the persistence of cccDNA in the nucleus of infected hepatocytes. The persistence of HBV in recovered patients even many years after the onset of the infection has been proved by: (a) the persistence of HBV-DNA and HBV-specific CD8 ${ }^{+}$cytotoxic T lymphocytes (CTLs), (b) the reactivation of $\mathrm{HBV}$ with $\mathrm{HBsAg}$ seroreversion while receiving immunosuppressive therapy, and (c) infections by liver transplantation to HBV non-immune recipients from donors with inactive infection [73-78].

Estimates indicate that virus reactivation can occur in approximately $20-30 \%$ of chronic carriers [79]. In carriers with inactive infection or with evidence of resolved hepatitis B, reactivation can occur and manifest itself by: (a) an active process of necroinflammation with a $\geq 5$-fold increase in serum ALT activity above the normal upper limit, (b) absolute increase on ALT levels $\geq 100 \mathrm{IU} / \mathrm{mL}$ associated to $\geq 1 \log _{10}$ elevation of viral load compared to the pre-exacerbation period, or (c) absolute HBV-DNA increase exceeding $10^{8}$ copies $/ \mathrm{mL}$ regardless of ALT activity levels [80]. The occurrence of reactivation often causes a flare of disease that can be severe and result in ALF; nevertheless, it could also be transient and clinically silent. Reactivations may resolve spontaneously in most instances, but if immune suppression continues, the re-establishment of chronic hepatitis occurs and can lead to progressive liver injury and cirrhosis [81]. 


\subsection{Chronic Hepatitis $B$}

The establishment of chronic infection is the result of the synergy between host and viral factors, and it occurs when viral clearance is ineffective. It is defined by the persistence of serum HBsAg for at least 6 months [61,70].

In 2017, the European Association for the Study of the Liver (EASL) proposed a new nomenclature for $\mathrm{CHB}$ stages. Its foundation is the two main characteristics of chronicity: infection vs. hepatitis [82]. The stages shown in Table 2 are defined by viral, biochemical, and fibrosis markers for liver disease; they are not necessarily sequential $[73,82]$.

Table 2. Viral and serological markers; and NK and T cells responses during chronic HBV stages.

\begin{tabular}{|c|c|c|c|c|c|}
\hline \multirow{3}{*}{ Phase } & $\mathbf{I}$ & II & III & IV & $\mathbf{V}$ \\
\hline & $\begin{array}{c}\text { HBeAg (+) } \\
\text { Chronic } \\
\text { HBV Infection }\end{array}$ & $\begin{array}{c}\text { HBeAg (+) } \\
\text { Chronic Hepatitis } \\
\text { B }\end{array}$ & $\begin{array}{c}\text { HBV Chronic } \\
\text { Infection HBeAg } \\
(-)\end{array}$ & $\begin{array}{c}\text { Chronic Hepatitis } \\
\text { B HBeAg (-) }\end{array}$ & HBsAg (-) \\
\hline & $\begin{array}{c}\text { HBeAg (+) } \\
\text { Non- } \\
\text { Inflammatory }\end{array}$ & $\begin{array}{c}\text { HBeAg (+) } \\
\text { Immune Active } \\
\text { Phase }\end{array}$ & Inactive Carrier & $\begin{array}{c}\text { HBeAg (-) } \\
\text { Immune Active } \\
\text { Phase }\end{array}$ & Occult Infection \\
\hline Previous term & Immune tolerant & $\begin{array}{c}\text { Immune reactive } \\
\mathrm{HBeAg}(+)\end{array}$ & Inactive carrier & $\begin{array}{c}\operatorname{HBeAg}(-) \\
\text { chronic hepatitis }\end{array}$ & Occult infection \\
\hline $\mathrm{HBeAg}$ & +++ & ++ & - & - & - \\
\hline Anti-HBe & - & + & + & + & + or - \\
\hline HBsAg & ++++ & +++ & $\begin{array}{c}++ \text { or }+ \\
\text { Few patients } \\
\text { develop } \\
\text { spontaneous } \\
\text { clearance } \\
(\sim 1 \% \text { annual })\end{array}$ & ++ & - \\
\hline Anti-HBs & - & +++ & ++ & + or - & + or - \\
\hline $\begin{array}{l}\text { HBV-DNA } \\
(\mathrm{IU} / \mathrm{mL})\end{array}$ & $10^{7}$ & $10^{4}-10^{7}$ & $\begin{array}{l}<2 \times 10^{3 * *} \text { or } \\
\text { undetectable }\end{array}$ & $>2 \times 10^{3}$ & $\begin{array}{l}\text { Very low levels in } \\
\text { liver and/or serum }\end{array}$ \\
\hline $\operatorname{ALT}(\mathrm{IU} / \mathrm{mL})$ & Normal & Elevated & Normal ( 40) & $\begin{array}{l}\text { Persistently or } \\
\text { intermittently } \\
\text { elevated }\end{array}$ & Normal \\
\hline Hepaticdisease & $\begin{array}{l}\text { None/minimal } \\
\text { necroinflammation } \\
\text { or fibrosis }\end{array}$ & $\begin{array}{l}\text { Moderate/severe } \\
\text { liver necroinflam- } \\
\text { mation and } \\
\text { accelerated } \\
\text { progression } \\
\text { of fibrosis }\end{array}$ & $\begin{array}{l}\text { None/minimal } \\
\text { necroinflammation } \\
\text { and low fibrosis }\end{array}$ & $\begin{array}{l}\text { Moderate/severe } \\
\text { necroinflammation } \\
\text { and fibrosis }\end{array}$ & $\begin{array}{l}\text { Immunosuppression } \\
\text { could lead to viral } \\
\text { reactivation. } \\
\text { Low risk of } \\
\text { cirrhosis or HCC }\end{array}$ \\
\hline \multirow[t]{2}{*}{$\begin{array}{l}\text { NK cells innate } \\
\text { response }\end{array}$} & $\begin{array}{c}\text { Impaired } \\
\text { production of } \\
\text { IFN- } \gamma \text { and TNF- } \alpha\end{array}$ & $\begin{array}{c}\text { Impaired } \\
\text { production of } \\
\text { IFN- } \gamma \text { and TNF- } \alpha \\
\text { Phenotypically } \\
\text { activated ( } \uparrow \text { NKp44 } \\
\text { in CD56 } 6^{\text {bright }} \text { and } \\
\text { CD69 in CD56 } 6^{\text {dim }} \\
\text { NK cells) }\end{array}$ & $\begin{array}{l}\text { Restored } \\
\text { production of } \\
\text { IFN- } \gamma\end{array}$ & $\begin{array}{c}\text { Phenotypically } \\
\text { activated } \\
(\uparrow \mathrm{NKp} 44 \text { in } \\
\text { CD56 bright and } \\
\text { CD69 in CD56 dim } \\
\text { NK cells) }\end{array}$ & \\
\hline & \multicolumn{5}{|c|}{ Normal NK cells cytolytic activity without differences in CD107a, perforin, or granzyme B expression. } \\
\hline $\begin{array}{l}\text { Global and HBV } \\
\text { specific } \mathrm{T} \text { cell } \\
\text { responses }\end{array}$ & $\begin{array}{c}\downarrow \text { IFN- } \gamma^{\#} \text { and } \\
\text { TNF- } \alpha\end{array}$ & $\begin{array}{c}\downarrow \text { IFN- } \gamma^{\#} \text { and } \\
\text { TNF- } \alpha\end{array}$ & $\begin{array}{c}\uparrow \text { HBsAg and } \\
\text { HBcAg response } \\
\text { producing IFN- } \gamma\end{array}$ & $\begin{array}{c}\uparrow \uparrow \text { IFN- } \gamma^{\#} \text { and } \\
\text { TNF- } \alpha\end{array}$ & \\
\hline Progress risk & $0.37 \%$ to $3.3 \%$ annu & progression risk & & & \\
\hline
\end{tabular}


Table 2. Cont.

\begin{tabular}{|c|c|c|c|c|c|}
\hline \multirow{3}{*}{ Phase } & I & II & III & IV & $\mathbf{V}$ \\
\hline & $\begin{array}{c}\text { HBeAg (+) } \\
\text { Chronic } \\
\text { HBV Infection }\end{array}$ & $\begin{array}{c}\text { HBeAg }(+) \\
\text { Chronic Hepatitis } \\
\text { B }\end{array}$ & $\begin{array}{c}\text { HBV Chronic } \\
\text { Infection HBeAg } \\
(-)\end{array}$ & $\begin{array}{c}\text { Chronic Hepatitis } \\
\text { B HBeAg (-) }\end{array}$ & HBsAg (-) \\
\hline & $\begin{array}{c}\text { HBeAg (+) } \\
\text { Non- } \\
\text { Inflammatory }\end{array}$ & $\begin{array}{c}\text { HBeAg (+) } \\
\text { Immune Active } \\
\text { Phase }\end{array}$ & Inactive Carrier & $\begin{array}{c}\text { HBeAg }(-) \\
\text { Immune Active } \\
\text { Phase }\end{array}$ & Occult Infection \\
\hline Others & $\begin{array}{c}\text { Very low rate of } \\
\text { spontaneous } \\
\text { HBeAg loss } \\
\text { Highly contagious. } \\
\text { More frequent and } \\
\text { prolonged in } \\
\text { carriers infected by } \\
\text { perinatal } \\
\text { transmission } \\
\text { Low efficacy of } \\
\text { currently } \\
\text { available } \\
\text { treatments }\end{array}$ & $\begin{array}{l}\text { Variable outcome, } \\
\text { but most of them } \\
\text { progress to stage } \\
\text { III }\end{array}$ & $\begin{array}{c}\text { Low risk of } \\
\text { developing HCC } \\
\text { or cirrhosis. } \\
\text { Loss of HBsAg } \\
\text { and /or } \\
\text { spontaneous } \\
\text { seroconversion } \\
\text { occurs in } 1-3 \% \text { of } \\
\text { cases }\end{array}$ & $\begin{array}{l}\text { A low proportion } \\
\text { of spontaneous } \\
\text { remission of the } \\
\text { disease }\end{array}$ & \\
\hline
\end{tabular}

Parameters based on the EASL 2017 Clinical Practice Guidelines [82]. NK cell and T cells responses were obtained from PBMC measures reported by Wang et al. [83]. ${ }^{* *} \mathrm{HBV}-\mathrm{DNA}$ can be between $2 \times 10^{3}$ and $2 \times 10^{4} \mathrm{IU} / \mathrm{mL}$ in patients without a signal of CHB. \# This is observed in patients, nonetheless controversial results are reported in animal models. Abbreviations: HBV, hepatitis B virus; HBeAg, HBV e antigen; HBsAg, HBV surface antigen; ALT, alanine aminotransferase; HCC, hepatocellular carcinoma; CD, cluster of differentiation; NK, natural killer cell; IFN- $\gamma$, interferon gamma; TNF- $\alpha$, tumor necrosis factor alpha; (+), positive; (-), negative; IU, international units; mL, milliliters; $>$, more than; <, less than; $\sim$, approximately; \%, percentage; $\uparrow$, an increase in the expression; $\downarrow$, a decrease in the expression.

\section{Immunopathogenesis of HBV Infection}

\subsection{Immune Response to HBV in the Evolution of the Infection}

$\mathrm{HBV}$ is a non-cytopathic virus, and the basis for liver disease seems to be immunemediated with CTLs inducing the death of infected hepatocytes [84,85]. During the progress of pathogenesis, different immune components are engaged, having interferon- $\gamma$ (IFN- $\gamma$ ) and CTLs concerted action as the main protagonists. In general, during AHB, viral infection is detected and restrained by a strong and robust immune response accompanied by viral clearance, whereas, in patients with $\mathrm{CHB}$, both innate and adaptive immune responses are weak and rarely achieve viral clearance [86].

\subsection{Response in $A H B$ Infection}

The main obstacle of studying the immune response during early AHB in humans is the difficulty of detecting and recruiting patients in the early stages of hepatitis B infection since most patients present the highest viremia before the onset of clinical manifestations and by the time of the typical presentation of jaundice, the maximal reduction in circulating HBV has already occurred. That is why the first evidence of the role of the immune response during the incubation period of the HBV (the time between infection and the onset of symptoms) came from animal models. Nevertheless, there are some relevant longitudinal studies performed in patients that follow from the clinically silent incubation to the recovery or clearance of HBV. A disadvantage is that this evidence came mainly from blood markers since performing a liver biopsy in patients with acute hepatitis is not recommended and involves ethical issues.

From these studies, the evidence suggests that in the early stages of acute infection, innate and adaptative responses play a role in which inhibition of viral replication and clearance of viral DNA could be mediated by natural killer (NK) cells, CD56 ${ }^{+}$natural T cells (NT), and CD4 ${ }^{+}$and CD8 ${ }^{+}$T cells (Figure 4) [87-89]. In patients with asymptomatic AHB with a transient low-grade viremia, NT cells producing IFN- $\gamma$ were detected before the highest peak of viremia, suggesting a non-cytolytic response involved in the initial 
viral control. It was followed by the maximum NK cell-cytotoxicity and IFN- $\gamma$ production at the time of the highest viremia [87]. At this point, $\mathrm{CD}^{+}$and $\mathrm{CD} 8^{+}$-mediated responses were still very weak, and NK/NT cells and their capacity for IFN- $\gamma$ production is dropped off quickly; these effects are correlated with an increase in IL-10 levels [87-89]. In a transgenic mice model, it was demonstrated that CTLs collaborate during the acute phase of infection by releasing tumor necrosis factor $\alpha$ (TNF- $\alpha)$ and INF- $\gamma$ without destruction of HBsAg positive hepatocytes [90]. These cytokines inhibit HBV replication and reduce cccDNA through the activation of nuclear apolipoprotein B mRNA editing enzyme, catalytic polypeptide-like 3G (APOBEC3) deaminase, which is responsible for HBV cccDNA degradation [91]. The viral DNA reduction performed mainly by INF- $\gamma$ and TNF- $\alpha$ precedes the liver damage, which is characterized by elevations of ALT levels in serum and T cells liver infiltration [86,89,92-94].

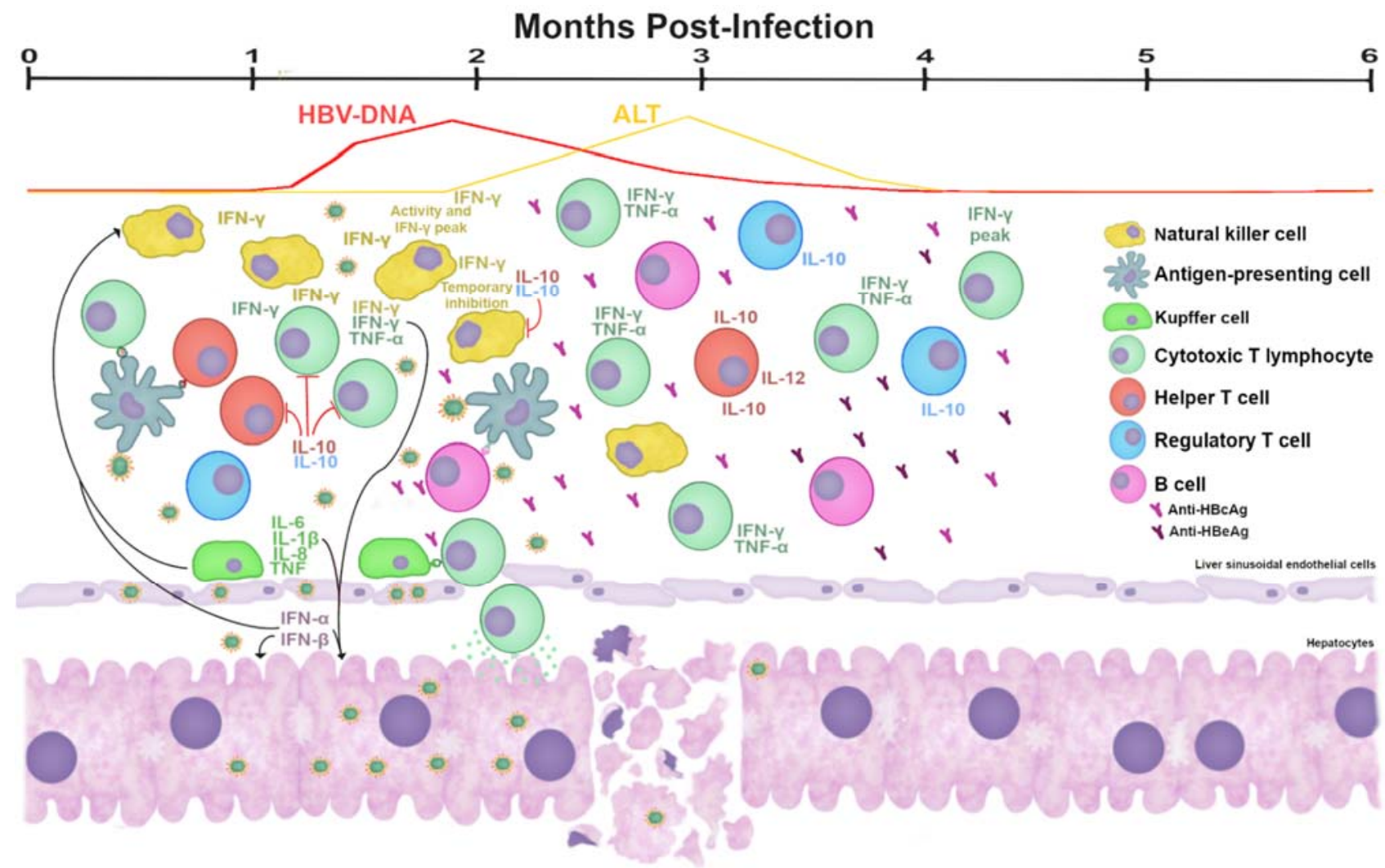

Figure 4. The potential dynamic of the immune response during AHB. Before the peak of HBV-DNA, the antiviral process is primarily mediated by non-cytolytic mechanisms, mainly by NK cells with IFN- $\gamma$ and TNF- $\alpha$ production. During this stage, the functions of $\mathrm{T}$ cells may be slowed down by regulatory cytokines. Infected hepatocytes collaborate by producing IFN- $\alpha$ and IFN- $\beta$ to fight the infection. KC cells could be participating by stimulating NK cells and by acting as antigen-presenting cells. After the peak of viral DNA in serum, the antiviral activity is performed mostly by T cells producing cytokines and antibodies (anti-HBc followed by anti-HBe). The cytolytic mechanism induced by HBV-specific CTLs leads to serum ALT increase. Serum HBV-DNA and ALT graphic was modified [95]. Cells and their secreted cytokines are in the same color. Trunked red lines indicate inhibitory effects. Abbreviations: HBV, hepatitis B virus; HBV-DNA, HBV DNA in serum; ALT, alanine aminotransferase; NK, natural killer; KC, Kupffer cell; IFN, interferon; IL, interleukin; TNF, tumor necrosis factor; CTL, cytotoxic T lymphocyte.

Another cell population involved is CD1d-restricted NKT cells; these cells are activated and have a role in the innate response by causing acute hepatitis and producing IFN- $\gamma$ and IL-4 in transgenic mice expressing viral antigens [96]. Along with cells of the immune system, hepatocytes produce interferon- $\alpha$ (IFN- $\alpha$ ) and interferon- $\beta$ (IFN- $\beta$ ), which inhibits viral packaging [97]. 
Early NK cells activation and capacity for IFN- $\gamma$ production were reduced during the viremia peak, and this reduction was correlated with increased IL-10 levels. Data has indicated that in patients with symptomatic AHB type I interferons (IFNs-I), IL-15, and IFN- $\gamma$ are not appropriately induced in response to the infection, but they found that in the early stages of AHB, there is induction of IL-10, and its surge accompanies the temporary inhibition of NK cells (at the peak of viremia) and T cell responses [88].

After the NK/NT cells decay in patients with AHB, the adaptative T cell response handled by $\mathrm{CD}^{+}$and $\mathrm{CD}^{+} \mathrm{T}$ cells increases progressively, reaching and sustaining (mainly by the $\mathrm{CD}^{+} \mathrm{T}$ cells subset) maximal IFN- $\gamma$ production when viremia is already undetectable. Interleukin 12 (IL-12) secretion by T cells reaches a peak before IFN- $\gamma$, while interleukin 4 (IL-4) and IL-10 production by CD4 ${ }^{+}$cells gradually increase, and the greatest production is observed when the secretion of Th1 cytokines (IFN- $\gamma$, IL-2, and TNF- $\alpha$ ) are already declining, and the anti-HBs antibody titers are increasing in serum [87-89].

In symptomatic AHB patients after viremia control, high levels of ALT were detected during 3-9 weeks [88,89]. The presence of HBsAg, HBeAg, and the increase in ALT and aspartate aminotransferase (AST) in serum characterized the acute infection [97]. In patients with resolved infection and self-limited swollen liver, viral clearance was performed by a strong immune response (vigorous, broad, and polyclonal) by specific $\mathrm{T}$ cells against HBV antigens $[84,95,98]$. After the clearance of viral antigens and the increase in ALT and AST, the appearance of anti-HBc followed by anti-HBe and anti-HBs antibodies take place. Anti-HBc (initially both IgM and IgG) appears one to two weeks after HBsAg secretion. IgG persists during chronic infection, and IgM-anti-HBc can be present in some patients with severe exacerbations of chronic HBV infection, though the title is lower than that during acute infection [84,86,92,97-99].

To counteract the liver damage resulting from the vigorous immune response, regulatory $\mathrm{T}$ (Treg) cells play an important role. In a murine model of acute HBV infection, an increase in the number of Treg cells was detected soon after the onset of HBV infection. These cells mitigate the immune-mediated liver damage through down-regulation of effector $\mathrm{T}$ cells, and as a consequence, the antiviral activity is hampered. However, these Treg cells do not influence the development of HBV-specific CTLs and memory T cells. Moreover, they seem to control the recruitment of innate immune cells to the liver [100]. These observations could support the idea that Treg cells increase at the beginning of the infection and favors non-cytotoxic mechanisms in this stage, delaying the liver damage and extending the virus clearance.

Studies in chimpanzees have shown that intrahepatic virus levels and histological evidence of inflammation are correlated with serum levels of HBV-DNA and ALT activity. CTLs mediate cytopathic mechanisms for the elimination of infected hepatocytes. The repertoire of $\mathrm{CD}^{+}$epitopes during acute infection is diverse for $\mathrm{HBVPol}, \mathrm{HBsAg}, \mathrm{HBxAg}$, and HBcAg. Responses to HBx and HBVPol were observed before viremia, followed by a reduction during viremia, and then $\mathrm{CD}^{+}$positive cells were recovered responding to HBVPol, $\mathrm{HBsAg}$, and $\mathrm{HBcAg}$. $\mathrm{CD}^{+} \mathrm{T}$ cells followed the same pattern of epitope recognition but were most responsive to $\mathrm{HBcAg}[84,86,92,97,98]$. In the absence of human biopsies, these pieces of evidence can be correlated with intrahepatic viral control and liver damage during the incubation period. All this data together could lead to ponder that the initial innate response against HBV is dominated by a non-cytolytic response mechanism mediated by NK cells, with minor participation of immune adaptative T cell response. Subsequently, liver damage markers are accompanied by the $\mathrm{CD}^{+} \mathrm{T}$ cells cytolytic effector activity. This evidence is supported by a model of acute woodchuck hepatitis virus infection [101].

\subsection{Response in CHB Infection}

During $\mathrm{CHB}, \mathrm{HBV}$ persistence is due to the accumulation of cccDNA in infected cells leading to the viral RNA transcription keeping up [95,102]. At this stage, due to the long-lasting exposure to viral antigens, $\mathrm{T}$ cells become exhausted and functionally 
impaired. Exhausted HBV-specific CTLs highly express inhibitory receptors (such as programmed cell death protein 1 (PD1); T cell immunoglobulin domain and mucin domain3 (TIM3); cytotoxic T-lymphocyte antigen 4 (CTLA4) and 2B4) [95,103-108]. In addition, $\mathrm{HBV}$-specific $\mathrm{T}$ cells are susceptible to apoptosis because of the increased expression of Bcl2interacting mediator (BIM) or TNF-related apoptosis-inducing ligand (TRAIL) receptor 2 (TRAILR2), which is targeted by TRAIL ${ }^{+}$liver NK cells. Added to this, the number of $\mathrm{CD}^{+} \mathrm{CD} 25^{+} \mathrm{FOXP}^{+}$Treg cells increases in blood and liver and suppresses HBV-specific effector T cells (Figure 5) [95,105,109-112].

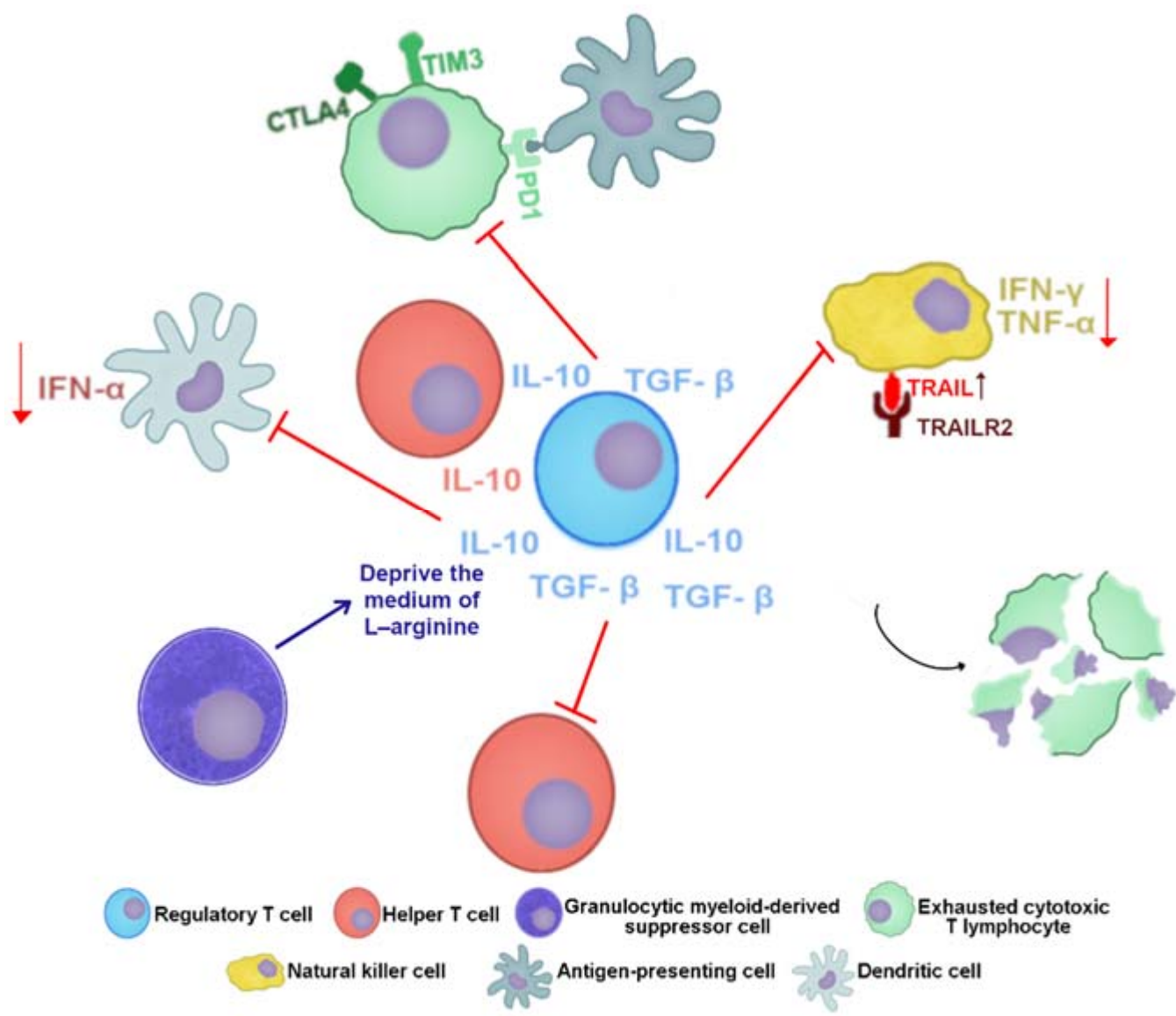

Figure 5. The induction of tolerant state during chronic hepatitis B. T cells are induced to an exhausted state; the secretion of IL-10 and TGF- $\beta$ by Treg cells inhibits the activity of immune cells such as DCs and NK cells. CTLs express higher levels of TRAILR2, which makes them susceptible to die by interacting with cells such as NK cells, which express higher levels of TRAIL in CHB patients. There is also metabolic regulation conducted by gMDSC sy consuming the L-arginine available in the medium. Cells and their secreted cytokines are colored the same. Trunked red lines indicate inhibitory effects, and red arrows indicate a reduction of secretion. Abbreviations: IFN, interferon; IL, interleukin; TGF- $\beta$, transforming growth factor- $\beta$; TNF, tumor necrosis factor; TRAILR2; or TNF-related apoptosis-inducing ligand (TRAIL) receptor 2; CTLA4, cytotoxic T-lymphocyte antigen 4; TIM3, T cell immunoglobulin domain and mucin domain-3; PD1, programmed cell death protein 1.

Although TRAIL expression is increased and the cytotoxic activity of NK cells is not impaired during chronic HBV infection, their activation and subsequent IFN- $\gamma$ and TNF- $\alpha$ production are strongly hampered. This functional alteration of NK cells is caused by immunosuppressive cytokines, such as IL-10 and transforming growth factor- $\beta$ (TGF$\beta)$, which are mainly produced by Kupffer cells (KC) and hepatic stellate cells (HSC), respectively, as well as by immune cells [113-115].

Dendrite cells (DCs) isolated from CHB patients and in vitro matured myeloid DCs (mDCs) have also decreased their allostimulatory capacity. The percentage of these cells, 
which express CD80 and CD86, is decreased as well as their capacity to produce TNF- $\alpha$ in response to stimuli. Similarly, isolated plasmacytoid DC (pDCs) from CHB patients produce fewer IFN- $\alpha$ in response to stimuli [116]. In addition to this response, it has been seen that circulating arginase I and granulocytic myeloid-derived suppressor cells (gMDSC), which are also accumulated in the liver, increase in HBV-replicating phases without immunopathology, and inhibits T cells by depriving them of L-arginine [117].

Studies in murine models that were generated by crossing female hemizygous HBV transgenic mice with male non-transgenic mice of the same genetic background resulted in HBV negative mouse pups (TGD mice). These mice were used to study the mechanism of HBV persistence after vertical transmission (hydrodynamic injection to introduce 1.3 mer HBV genomic DNA into mouse hepatocytes). The results showed that KCs mediate the impairment of CTLs' response, favoring HBV persistence in these mice. Maternal HBeAg could play an important role in up-regulating the inhibitory ligand PD-L1 on $\mathrm{KCs}$; as a consequence, TGD mice macrophages could be sensitized by maternal HBeAg since this antigen could be able to cross the mouse placenta or it could be delivered during colostrums' feeding. Binding PD-1 and PD-L1 between CD8 ${ }^{+} \mathrm{T}$ cells and hepatic macrophages were responsible for CTLs exhaustion in offspring of HBV-infected TGD mice [118]. Another study performed in a murine model of HBV persistence-induced systemic tolerance supports the role of IFN- $\gamma$ as an inductor of tolerance. HBV antigens persistence induced sustained IFN- $\gamma$ secretion by hepatic (T helper) Th cells; this cytokine promotes CXCL9 secretion from KCs and supports the retention of antiviral CD4 ${ }^{+} \mathrm{T}$ cells in the liver and their eventual apoptotic elimination partially via CTLA4 ligation [119]. IFN- $\gamma$ may have a dual role during HBV infection; on one hand, it is known its relevant role in the spontaneous elimination of HBV at the onset of the infection; on the other hand, IFN- $\gamma$ contributes to maintaining liver tolerance. The specific $\mathrm{T}$ cell differentiation pattern defined by the cytokines surrounding the liver tissue could influence the IFN- $\gamma$ role.

In HBV-infected patients, expression of IL-22 is increased compared to healthy subjects. IL-22 seems to induce migration of intrahepatic Th17 cells and promotes the progression of liver fibrosis in CHB patients [120]. Furthermore, patients with cirrhosis associated with hepatitis B with more severe disease have an increase in Th17 cells and IL-17 in plasma [121]. Both interleukins could play a role in promoting HSCs activation secreting several chemokines to promote Th17 cell chemotaxis [120,121].

Longitudinal and transversal studies performed in patients with $\mathrm{CHB}$ and animal models with viral persistence make clear that a weak adaptative immune response, which could emerge as a consequence of an inadequate innate response, is the most related cause of chronicity. This immune failure allows a sustained HBV replication, transcription, and translation of its genome products. These products lead to an increase in the HBV-DNA, RNA, and viral proteins, causing qualitative and quantitative changes in hepatic and blood cytokines, which impair the immune system and favor the viral persistence and mutation. Even with all the scientific progress on this topic, it is necessary to increase research, especially in geographical regions where only a few studies are giving scarce information on the HBV genotypes that are prevalent in those areas.

\section{Acute Liver Failure in HBV Infection}

HBV-associated acute liver failure (ALF) (also known as fulminant hepatitis B) is a dramatic clinical syndrome ending with a fatal outcome or liver transplantation in most cases. ALF occurs when the regenerative capacity of the liver is overcome by the rate and extent of hepatocellular death. ALF may occur after acute HBV infection in a person without previous liver disease (primary infection) or during an acute exacerbation of $\mathrm{CHB}$, leading to multiorgan failure. ACLF can occur spontaneously or as a result of immunosuppression due to chemotherapeutic or immunosuppressive agents [122]. 


\subsection{Liver Failure in Acute Infection}

ALF is characterized by the presence of coagulopathy and hepatic encephalopathy in the absence of prior hepatic disease. ALF may be the result of an exaggerated immune response. Noteworthy, patients that survive without liver transplantation will seroconvert their HBsAg status (HBsAg negative/anti-HBs antibodies positive) and will not develop chronic hepatitis [123].

Coexisting factors, such as alcoholic hepatitis and co-infection with hepatitis delta [124], are associated with HBV-ALF. In addition, infection with $\mathrm{HBV}$ harboring double BCP mutation (A1762T/G1764A), pre-core mutations G1986A, G1899A, and A2339G, predominantly HBeAg negative, genotype $\mathrm{B} 1 / \mathrm{Bj}$, and higher levels of HBV-DNA is common in ALF compared to patients with acute self-limited hepatitis B [125].

To investigate the molecular bases of liver damage on the site of HBV replication, interesting research has been performed using liver samples from patients with HBVassociated ALF and chimpanzees with classical acute hepatitis for comparison. All patients with ALF were infected with $\mathrm{HBV}$ /genotype D. In addition to pre-core stop codon mutation G1896A that was invariably present in ALF, they also identified two to three amino acid changes in the B cell epitope (aa 73-85). These mutations were associated with increased $\mathrm{HBcAg}$ expression ex vivo and were absent in chimpanzees and patients with acute hepatitis B. Moreover, liver gene and miRNA expression profiles in ALF patients showed an up-regulated intrahepatic $B$ cell gene signature promoting $\operatorname{IgM}$ assembly and secretion, targeting $\mathrm{HBcAg}$ with nanomolar or even picomolar affinities, followed by the complement cascade activation with the subsequent massive liver necrosis [126].

\subsection{Acute-on-Chronic Hepatitis B Liver Failure}

Patients with a poor outcome of HBV-related acute-on-chronic liver failure (ACLF) had an increase in Treg cells, and these cells were redistributed from periphery to liver. Besides, these cells were located mainly in areas with an inflammatory profile or with a lymphocyterich profile, supporting their role in the liver damage and inflammation since this cell pattern was not observed in normal liver. Additionally, there was a positive correlation con HBV-DNA loads and circulating Treg cells [127]. Additional studies to understand the effect of Treg cells and ACLF must be performed; nonetheless, it is possible that high levels of peripheral Treg cells in non-survivors do not restrain the liver inflammation due to severe uncontrolled immune modulation.

Serum levels of IL-1 $\beta$, IL-6, IL-8, IL-10, and TNF- $\alpha$ in patients with ACLF were significantly higher compared to the normal control group. Besides, it was found that IL-10 increased before the time of diagnosis, and this increase was positively correlated with the ALT level [128]. In a comparative study performed in patients with ACLF who eventually died, patients with ACLF who survived, and patients with mild-moderate CHB, the IL-1, IL-10, and TNF- $\alpha$ levels were significantly higher in the group of patients who died. These cytokines have an important role in the antiviral activity; nevertheless, their increase with the concomitant failure in viral clearance in patients with ACLF who die might reflect the degree of liver inflammation and damage. Additionally, IL-12 in the non-survival group was higher than in the survival group at the diagnosis stage, indicating an intensive reaction that tries to eliminate the viral infection [129]. Nonetheless, there are contradictory results about the IL-10 levels in CHB patients [130-133]; further studies with a huge number of patients must be performed. In CHB patients with ALF, the levels of TGF- $\beta 1$ and IL-31 (a member of the IL-6 family) are significantly increased with a positive correlation with total bilirubin (Tbil) and $\alpha$-fetoprotein (AFP). In those patients who recovered from liver injury, TGF- $\beta 1$ and IL-31 levels decreased; and in non-survivors, they were markedly up-regulated. The TGF- $\beta 1 /$ IL-31 pathway has been associated with disease severity in HBV-related liver cirrhosis [134] and could play an important role in the pathogenesis of liver injury in ACLF [135].

Additionally, in the previously mentioned reports, a Th17/Treg axis imbalance that could have a role in the development of ALF in CHB has been observed. Nevertheless, as 
well as the studies related to IL-10, the results are diverse; in some studies, it was found a higher frequency of Th17 cells in ACLF, whereas others did not find significant changes in Treg cells [136-139].

\subsection{Viral Factors in ACLF}

Most of the studies that analyze viral markers in HBV-ACLF patients have been made in Asia, where genotypes B and C predominate. HBV genotype B has been associated with the risk of ACLF. Even so, it is important to highlight that an associated risk with the HBV genotype in ACLF was not found in a meta-analysis [140]. Some potential identified triggers of ACLF are the presence of mutations in the pre-core/core region, mainly the precore G1896A mutation and BCP A1762T/G1764A double mutation [141-143]. In addition to the previous mutation referred, a more frequent mutation index in Pre-S, HBcAg (aa 90-135 in genotype $C$ and aa 60-130 genotype B), and HBxAg (aa 131-135) regions were identified in ACLF patients compared to acute hepatitis, chronic hepatitis, and immune tolerant HBV carriers by sequencing a total of $606 \mathrm{HBV}$ full-length genomes (from 49 treatment-naïve HBV-infected patients) [144]. The mechanism with the presence of these mutations and their clinical significance needs to be further investigated. It is to mention that information related to other HBV genotypes is scarce at this clinical stage; therefore, it is a must to increase these kinds of studies in geographical areas where different genotypes from $B$ and $\mathrm{C}$ are prevalent.

\section{Sensing and Response to $\mathrm{HBV}$}

The host cells involved in the recognition of HBV are hepatocytes, hepatic nonparenchymal cells, and innate immune cells [145].

- Hepatocytes: Primary human hepatocytes (PHHs) and differentiated HepaRG (dHepaRG) cells express pattern recognition receptors (PRRs) such as retinoic acid-inducible gene-I (RIGI), melanoma differentiation-associated protein 5 (MDA5), and most Tolllike receptors (TLRs). Both RIGI and MDA5 are important for sensing viral RNAs during viral infections [146]. After the recognition of viral RNAs, these receptors induce the stimulation of an IFN- $\beta$ promoter, increasing the synthesis of this antiviral cytokine. The loss of MDA5 in Huh7 cells and in MDA5 knockout mice caused an increase in HBV replication; however, the overexpression of MDA5 did not impact IFN- $\beta$ induction. In that same study, it was found that RIGI did not inhibit viral replication [147]. In contrast, the recognition of the epsilon region of the pgRNA by RIGI and how this recognition not only induced the production of type III IFNs but also counteracted the interaction of HBVPol with the pgRNA [148]. Infection of PHHs cells and dHepaRG with HBV induced a weak and transient innate response (production IL-6, IL-29 and type I IFNs) [149]. Another in vitro model of micropatterned cocultures of PHHs with stromal cells (MPCCs) incubated with HBV-infected serum stimulated the expression of interferon-stimulated genes (ISGs) (Figure 6) [150].

The innate nuclear sensor interferon-inducible protein 16 (IFI16) can recognize the cccDNA and even play an antiviral role by mediating epigenetic regulation of the viral chromatin. On the other hand, it was found that IFI16 is downregulated in HBV-infected hepatocytes and in CHB patients [151].

It was recently demonstrated in monocyte-derived dendritic cells (MDDCs) that HBV-RNAs (including mRNAs and pgRNA) are not immunostimulatory, but naked HBVDNA can be sensed by the cyclic GMP-AMP synthase/stimulator of interferon genes (cGAS/STING) pathway (Figure 6). Again, it was noticed that this pathway is expressed at low levels in $\mathrm{PHH}$, being unable to respond to productive HBV infection, but it is able to sense naked HBV-DNA when it is present in sufficient amounts [152]. 


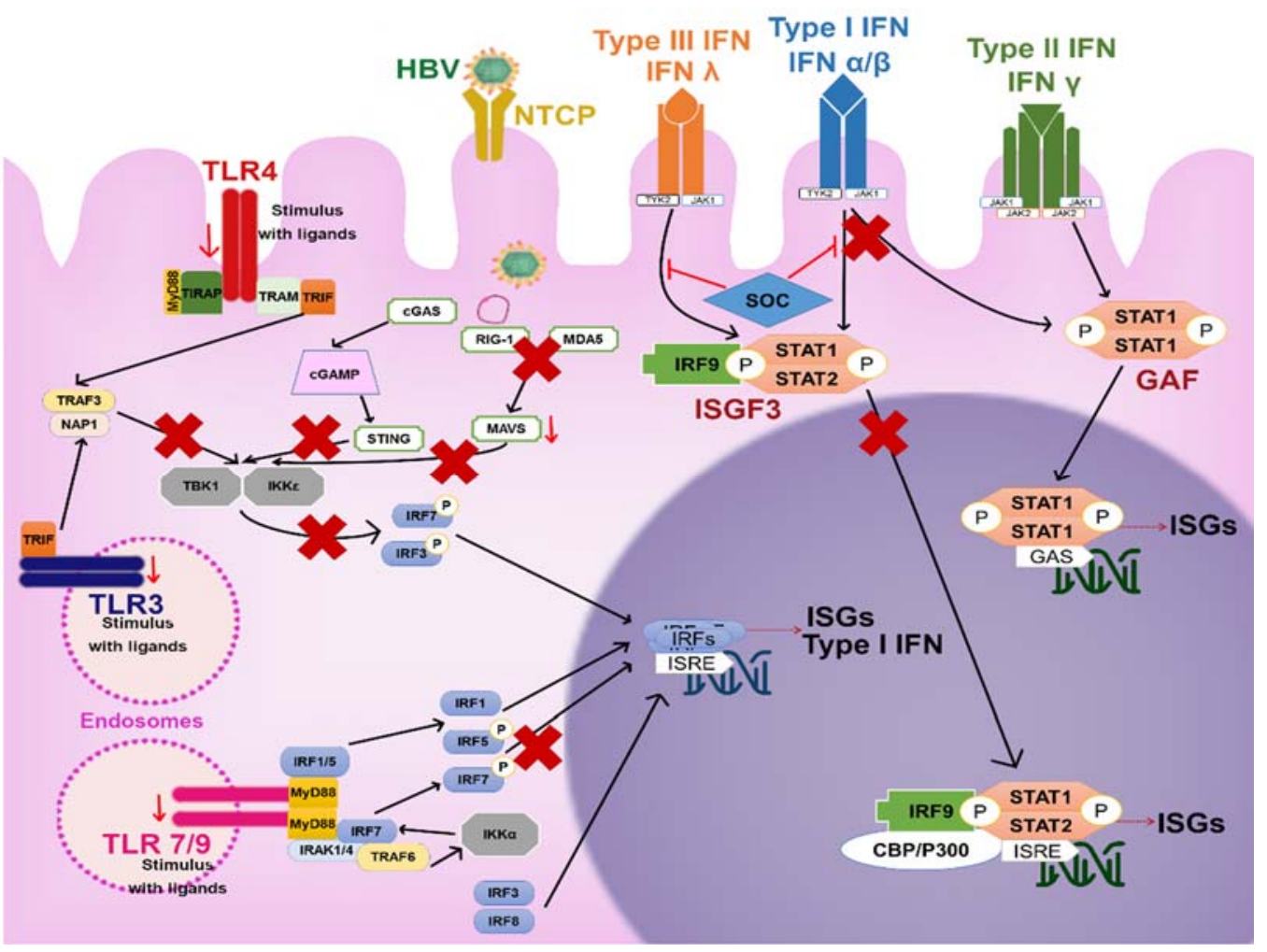

Figure 6. Probable signaling in the mechanism induced by TLRs, IFNRs, RIG-I, and STING in the control of the viral infection and how the virus interferes with them (marked with a red X). The stimulus of TLRs can induce a response to eliminate HBV. HBV presence leads to downregulation of the expression of TLRs (observed in PBMCs; indicated with red arrows) and/or interfere with its signaling (blocking the MyD88-IRAK4 axis, suppressing IRF3 activation, inhibiting the expression and nuclear translocation of IFR7). The virus can also inhibit RIG-I/MDA5-mediated response and STINGstimulated IRF3 activation; blocks: the activation of interferon IRF3 and IRF7, TBK1/IKKE activation, STING-stimulated IRF3 activation and, down-regulate the expression of MAVS. The presence of the virus can also interfere with IFN receptors signaling by avoiding nuclear translocations of STAT1/2 and IFN- $\alpha$-induced STAT activation. Abbreviations: HBV, hepatitis B virus; NTCP, Na+-Taurocholate co-transporting polypeptide; TLR4, Toll-like receptor 4; TLR7/9, Toll-like receptor 7 and 9; MyD88, Myeloid differentiation primary response 88; TIRAP, TIR domain-containing adaptor protein; TRAM, TRIF-related adaptor molecule; TRAF, TNF Receptor Associated Factor; NAP1, NF-kB-activating kinase-associated protein 1; IRF, interferon regulatory factor; TBK1, TANK binding kinase 1; IKK $\varepsilon$, IКB kinase- $\varepsilon$; STING, stimulator of interferon genes; STAT, signal transducers and activators of transcription; IRF9, IFN regulatory factor 9; ISG, interferon stimulated genes; ISGF3, ISG factor 3; SOC; IFN-induced suppressor of cytokine signaling; GAS gamma IFN activated sequence (GAS) gamma IFN activated sequence GAS; MAVS, mitochondrial antiviral signaling; cGAMP, cyclic-GMPAMP; cGAS, cyclic-GMP-AMP synthase; GAF, IFN- $\gamma$ activated factor.

- Hepatic non-parenchymal cells: Liver sinusoidal endothelial cells (LSECs) play a key role in the uptake of viral particles circulating in the blood to infect adjacent hepatocytes. LSECs seem to be unable to replicate the virus, but they may serve as a reservoir of endogenous reinfection. They produce large amounts of anti-inflammatory cytokines (such as TGF- $\beta$ ) and constitutively express major histocompatibility complex-I restricted antigens and co-stimulatory molecules that could favor the shift of the hepatic immune balance towards tolerance [153,154].

In vitro assays have proved that $\mathrm{KC}$ (even while being uninfected) are able to sense the HBV and activate nuclear factor kappa B (NF-kB); subsequently, these cells release IL-6 and other pro-inflammatory cytokines (IL-8, TNF- $\alpha$, and IL-1 $\beta$ ) transiently; although, there is no induction of IFN response. IL- 6 activates the mitogen-activated protein kinases exoge- 
nous signal-regulated kinase $1 / 2$ and c-jun $\mathrm{N}$-terminal kinase, which inhibits hepatocyte nuclear factor (HNF) $1 \alpha$ and HNF $4 \alpha$ expression, two essential transcription factors for HBV gene expression and replication [155].

- Dendritic cells: The exposure of $B D C A 1^{+} \mathrm{mDC}$ to $\mathrm{HBsAg}$ results in their strong maturation, cytokine production, and an enhanced capacity to activate antigen-specific CTLs. It was also found that CD14 and TLR4 play a crucial role in the HBsAg-mediated DCs maturation [156].

\section{Viral Epitopes}

Many HBV variants that present mutations within B and/or T cell epitopes have been identified. An example is the rtI $169 \mathrm{M}$ mutation that also affects the T cell epitope located from 157 to 162 aa in the HBsAg [157]. In addition, multiple mutations in the core gene, as well as the G1896 pre-core mutation, were identified in patients during the immune clearance phase or in the low replicative phase, while in patients during the immune tolerant phase, only minimal changes were identified. These findings support that evolution of new HBV variants may be induced mainly by the host immune pressure rather than viral reverse transcription error rate [158].

The emergence of HBV mutants causes the existence of heterogeneity (genetic and antigenic) among the virus variants throughout the population and even in an individual. A systemic review from 2008 showed that there is a significant variation of T-cell epitopes between the HBV genotypes [159].

\section{1. $H B s A g$}

The HBsAg contains four conserved trans-membrane (TM) regions consisting of an $\alpha$ helix structure that maintains the stability of the protein structure. The targets of $\mathrm{T}$ cell and $\mathrm{B}$ cell epitopes in the HBsAg are concentrated in the hydrophilic loops between the $\alpha$-helices that harbor more variable aa residues. That includes the major hydrophilic region (MHR, aa 99-160), which contains a conformational B cell epitope cluster. In addition, the core part of MHR denominated as "a" determinant (aa 121-147) harbors a cluster of epitopes targeted by neutralizing anti-HBs antibodies $[10,160,161]$. Escape mutants' emergence within the "a" determinant (induced or not by vaccination) and how they can affect the host immune response has been previously reported by several studies [162-164]. The presence of these mutations in the B cell epitopes has been associated with conformational changes that may lead to vaccine escape, diagnosis failure, and immune tolerance [157,161,165-167].

\subsection{Immune Escape Mutations and Diagnosis Failure}

HBsAg is a major viral protein in the induction of protective immune response. The detection of this protein in serum is the main diagnostic tool of the infected individuals. The most common HBV mutants associated with immune escape are those with changes in aa 145. Furthermore, there are mutations in the $S$ gene that result in occult HBV infection (presence of HBV-DNA in the absence of HBsAg) [168,169].

A large-scale analysis $(n=6434)$, found that immune escape mutations were present in $10.7 \%$ of the sequences (I/T126S, 1.8\%; G145R, 1.2\%; M133T, 1.2\%; and Q129R, 1.0\%), being G145R the first vaccine escape mutant identified and I/T126S the most frequent [9]. These mutations have been previously related to vaccine failure $[170,171]$. These studies have identified aa 126 (I126S/N and T126A, 29.63\%) and aa 145 (G145R/A, 25.93\%) as the hottest mutations post immunization period [9,170,171].

A study performed in Argentina that analyzed HBsAg and HBVPol sequences from 530 samples of HBV-infected individuals found that diagnostic failure mutants (DFM) and vaccine escape mutants (VEM) were detected in $10.7 \%$ and $7.5 \%$, respectively. The most frequent DFM was Y100C in subgenotype A1 and was frequently detected in HBsAg negative samples [172]. Despite that, even if this mutation has been frequently identified in the lack of HBsAg detection in serum samples, in vitro assays suggested that this substitution alone is not enough to evade HBsAg detection by commercial ELISA assay [173]. 
In 2020, it was found that the overall frequency of escape mutations is low and evenly distributed among genotypes; only P127H/L mutations (associated with occult infection) appear to be the wild-type amino acid for genotypes $\mathrm{E}, \mathrm{F}$, and $\mathrm{H}(96.8 \%, 98.9 \%$, and 97.7\%) [23,157].

Another interesting observation is that HBV reactivation in patients with resolved infection seems to be triggered by an immunosuppressive status, characterized by the expansion of variants associated with immune escape and with MHC class II-restricted T cell epitope variants (L21S and/or F220C variants in the S-HBsAg) and/or impaired virion secretion (E2G, L77R, L98V, T118K, and Q129H in the S region, and M1I/V in the pre-S2 region) [174].

\section{3. $\mathrm{HBCAg}$ and $\mathrm{HBeAg}$}

Mutations at pre-core can affect the structure of the HBeAg and even eliminate its expression. For example, the mutation G1896A creates a stop codon that not only avoids the expression of the HBeAg but also strengthens the secondary folding structure of the encapsulation signal on the viral pgRNA and leads to an increase in viral replication. This mutation affects the immunological response because the presence of HBeAg normally stimulates regulatory $\mathrm{T}$ cells that suppress $\mathrm{T} \mathrm{CD} 8^{+}$cells against $\mathrm{HBcAg}$. This mechanism evokes an unregulated immune response against infected hepatocytes, lowers the viral load, and diminishes the infectious state. HBeAg negative infections are frequently characterized by higher nucleotide diversity compared to HBeAg positive infections. This behavior is probably explained by the increase in the replication rate, combined with an increasing selection pressure in $\mathrm{HBcAg}$ [7].

The major immunodominant regions of the $\mathrm{HBcAg}$ have been mapped to residues 78-83. Around the most protruding HBcAg region (aa 71-87), there are the major B cell epitopes to HBV mainly between aa 76 and 82; another B cell epitope lies around aa 129-132. [175,176].

The characterization from 1 to 150 aa sequence in $\mathrm{HBcAg}$ strains from patients infected with genotype $\mathrm{D}$ found that mutations in $\mathrm{HBcAg}$ were more frequent in those strains from asymptomatic carriers than HBeAg negative patients with CHB. Additionally, HBV-DNA serum was inversely associated with the presence of mutations in CTLs epitopes of HBcAg, while it was directly associated with the presence of double promoter T1762/A1764 together with G1757 mutations. This inverse correlation of HBV-DNA level and CTL escape HBcAg mutations in HBeAg seroconverted patients with $\mathrm{CHB}$ favors CTL escape mutations selection. This correlation also establishes the persistence of HBV infection despite viral fitness reduction [176].

HBcAg peptide from aa 81 to 95 elicits IFN- $\gamma$ by $\mathrm{CD}^{+} \mathrm{T}$ cells, and from aa 131 to 145 induces IFN- $\gamma$ and IL- 2 production by CD8 ${ }^{+}$and $\mathrm{CD}^{+}{ }^{+} \mathrm{T}$ cells in favor of HBV clearance [87].

\section{The Role of TLRs}

Toll-like receptors (TLRs) might have a real role in the clearance of HBV [97]. There are various studies of the interaction between TLRs and HBV, but there is no convincing evidence of HBV proteins, viral RNAs, and HBV-DNA being truly recognized by TLRs. Regardless of the fact that TLRs mediated innate immunity is not, or only weakly activated by HBV infection, experimental activation of the TLR system was able to suppress HBV replication in vitro and in vivo [177].

Specific ligands for TLR3, TLR4, TLR5, TLR7, and TLR9 had the ability to control HBV replication in HBV transgenic mice in an IFN dependent manner. In the HepG2 cell line, ligands of TLR2, TLR3, TLR4, TLR7, and TLR9 were reported to suppress HBV replication. Besides, in this cell line, the overexpression of TIR-domain-containing adapter-inducing interferon- $\beta$ (TRIF), IFN- $\beta$ promoter stimulator 1 (IPS), as well as myeloid differentiation primary response 88 (MyD88) was found, which may be involved in the suppression of HBV replication (Figure 6) [145,178]. 


\section{Interferon Response}

$\mathrm{HBV}$ is usually referred to as a stealth virus; however, some studies have shown that the virus can be sensed by immune cells and induces IFNs response. It has been demonstrated by in vivo and in vitro models that the production of type I INFs (IFN- $\alpha$ and IFN- $\beta$ ) is poorly induced during HBV infection $[148,179,180]$. Even though HBV does not trigger type I IFN production, IFN- $\alpha$ and $-\beta$ can suppress HBV replication in vitro and in HBV transgenic mice models. Recombinant IFN- $\alpha$ has been approved and successfully used as a standard treatment for chronic HBV infection [178]. Some of the ISGs induced by IFN and their role against HBV are reviewed by Pei and Lu, 2014 [178].

A genome-wide association study that tried to identify genetic variants associated with early sustained response to peg-IFN in CHB patients did not find any significant hits but found that G3BP2 rs3821977 was associated with peg-IFN response in HBeAg negative patients. G3BP2 has a role in the IFN pathway. G3BP2 G-allele differentially affected interferon-inducible protein 10 (IP-10), IL-10, and IL-8 protein expression [181].

\section{HBV Genotypes in the Response to IFN}

HBV genotype is a predictor of IFN treatment. Among HBeAg-positive patients, genotype A infection is associated with a higher rate of HBeAg and HBsAg loss. Studies in Asia have shown that genotype B is associated with a higher rate of HBeAg loss compared to genotype C. Similar findings have been demonstrated among HBeAg negative patients, with better response rates in patients with genotype A versus genotype D [182].

However, it was observed in cell culture-based HBV infection models that the sensitivity of HBV to IFN- $\alpha$ in hepatocytes may be determined more by the cell-intrinsic IFN response than by the viral genotype [183].

An IFN-stimulated response element (ISRE)/IFN regulatory element (IRE) has been identified in the EnhI/X gene promoter region of the HBV genome (nt 1091-1100) [184]. It has been observed that a single base mutation on this region can affect IFN response; for example, a single change in the fourth base $(C \rightarrow T)$ may partially decrease the effect of IFN [185]. This base change could be the reason why genotype $B$ has a relatively higher response to IFN- $\alpha$ therapy compared to genotype C [186].

The expression of spliced variants-HBV splice-generated protein, a major spliced HBV-RNAs-encoded proteins (truncated TP domain) and N-terminal-truncated viral polymerase protein (common in most of the known spliced HBV variants) — result in strong suppression of IFN- $\alpha$ signaling transduction in CHB patients) [187].

\section{HBV Interference against the Antiviral Activity}

Only around $30 \%$ of $\mathrm{CHB}$ patients respond well to treatment with exogenous IFN$\alpha[188,189]$. There is evidence that HBV has mechanisms to counterattack type I IFNs signaling routes. Even though it has been seen that HBV can slightly induce interferon production in some models, it has been proven that the virus also performs strategies to go against those defense mechanisms of the cell. For example, the expression of TLR2, TLR3, TLR4, TLR7, and TLR9 in peripheral blood mononuclear cells (PBMCs) was reduced in chronically HBV-infected patients; this reduction could be the result of the exhaustion of the TLR system under continuous activation.

In hepatitis B patients, pDCs frequency is decreased (inversely correlated with ALT levels and viral load), and TLR9 expression is reduced, as well as in PBMCs and pDCs from the HBV group, the production of IFN- $\alpha$ is impaired (inversely correlated with serum viral load of HBV) [190,191]. Internalized HBV particles inhibit TLR9-mediated secretion of IFN- $\alpha$ and down-regulating TLR9 transcriptional activity in pDCs and B cells. These changes can interfere with TLR9 activity by blocking the MyD88-IRAK4 axis and Sendaivirus-targeting IRF7 to block IFN- $\alpha$ production. In $\mathrm{HBV}$ genotypes $\mathrm{A}-\mathrm{H}$, neutralizing CpG motif sequences that have a suppressive effect on TLR9-immune activation have been identified, and they could reduce IFN- $\alpha$ secretion [192]. 
In PBMCs from HBV-infected patients, TLR-mediated cytokine expression (IL-6 and IL-10) and TLR3-induced interferon expression is higher compared to healthy controls. In addition, TLR3 mediated IFN- $\gamma$ is inhibited in the presence of serum that contains HBV. In the presence of HBV, KCs and LSECs are stimulated by TLR3 ligands; consequently, IFN- $\gamma$, interferon sensitive genes, and proinflammatory cytokines are suppressed, as well as the activation of $\mathrm{T}$ cells through TLR3-stimulation [193].

A TLR3-diminished expression in CHB patients has been reported, but it could be restored after entecavir treatment and at a greater recovery degree with peg-IFN treatment [194]. Reduced expression of TLR3 was also found in patients with active chronic hepatitis B compared to asymptomatic carriers; however, in contrast to Huang's study, they did not find a significant difference in comparison with healthy controls [195].

HBsAg, HBeAg, or HBV nullify TLR-induced antiviral activity by suppressing IFN- $\beta$ production and subsequent interferon-stimulated gene induction, as well as suppressing interferon regulatory factor 3 (IRF3) activation, NF- $\mathrm{KB}$, and extracellular signal-regulated kinase (ERK) 1/2. In HBV-Met cells infected with HBV, TLR stimulation does not induce antiviral cytokines in contrast to primary hepatocytes. The expression of proinflammatory cytokines (TNF- $\alpha$ and IL-6) stimulated by TLR and activation of IRF-3 is suppressed after up-regulation of HBV replication in HBV-Met cells [196].

PHHs cells and dHepaRG cells infected with HBV induced a weak and transient innate response (production IL-6, IL-29, and type I IFNs). It was also observed that TLR3 and RIGI/MDA5-mediated innate response was inhibited by factor(s) in the HBV inoculums (but not being HBsAg or HBeAg) [149].

\section{Interference by Viral Proteins}

\section{(a) HBsAg}

HBsAg inhibits the IFR7 expression and nuclear translocation, which results in the suppression of IFN- $\alpha$ production mediated by TLR9 [197]. A correlation between the level of HBsAg in plasma and the impairment in the cytokines production was identified after a challenge to TLR2 and TLR4 ligands on PBMCs from CHB patients, along with observations of lower expressions of TLR1, TLR2, TLR4, and TLR6 on these cells [198].

\section{(b) HBVPol}

The viral polymerase interferes with TLR3 and RIGI signaling by blocking the activation of interferon regulatory factors 3 and 7 (IRF3 and IRF7). HBVPol interacts with the DDX3 DEAD-box RNA, which normally is in charge of activating TANK-binding kinase 1 (TBK1) and IKB kinase- $\varepsilon$ (IKK $\varepsilon$ ) [199].

STING is a central factor for foreign DNA recognition and antiviral innate immunity. HBVPol inhibits STING-stimulated IRF3 activation by binding HBVPol RT and RNaseH domains with STING, leading to an extreme decrease in STING's K6-linked polyubiquitination, which is associated with a loss of its functions [200]. Additionally, HBVPol avoids nuclear translocations of signal transducer and activator of transcription $1 / 2($ STAT1/2) via competitive bidding to importin- $\alpha 5$ and suppresses STAT1 Ser727 phosphorylation by inhibiting protein kinase $C$ delta type (PKC- $\delta$ ) activation, which together impairs IFN- $\alpha$ induced STAT activation (Figure 6) [201].

\section{(c) HBX}

The $\mathrm{X}$ protein of the HBV downregulates the expression of mitochondrial antiviral signaling (MAVS), which is an important virus-activated signaling pathway that activates NF-kB and IRF3 (Figure 6) [202].

\section{Conclusions}

The scientific advances on hepatitis B since the discovery of HBsAg in 1965 have been evidenced by the improvement of serologic and molecular diagnosis, in addition to the development of effective recombinant vaccines and the antiviral treatments that already control viral replication. However, even if vaccines and antiviral treatments are widespread 
in the world, low-income and middle-income countries are in trouble to prevent or treat this infection due to the high cost involved in vaccine coverage or for an efficient long-term treatment. Nonetheless, current therapy is not a real cure for the infection, and that is why researchers keep trying to come up with new alternatives for treatment that lead to a cure, such as HBV inhibitors entry as NTPC inhibitors. Moreover, the most significant challenge in the HBV cure is to achieve cccDNA eradication and to block HBV genome integration into the human genome.

Most of the knowledge about HBV genetic variability and clinical implications on hepatitis B comes from longitudinal and transversal studies performed in countries where hepatitis B has been a serious health problem. Those countries have been classified as regions with a high or intermediate prevalence of $\mathrm{HBsAg}$, with an elevated risk to develop chronic hepatitis and end-stage liver diseases where the most frequent genotypes are A, B, C, and D. Nevertheless, there is scarce information about the genotypes F, G, E and $\mathrm{H}$, which are endemic at low or medium-income countries where the disease might be sub-diagnosed.

Hepatitis B clinical presentations and evolution varies depending on the host's genetic background and HBV variability. That is the reason why we considered reviewing the most relevant aspects of the molecular bases during a hepatitis B infection from clearance to chronic liver disease, including HBV molecular aspects. Therefore, relevant data reviewed has shown us that during the early stages of acute HBV infection, the initial innate response seems to be mainly dictated by the non-cytolytic activity of NK cells followed by cytolytic T cells response accompanied by liver damage. Treg cells play an important role in HBV non-cytolytic clearance reducing the liver damage induced by CTLs. Virus clearance is correlated with a wide and strong immune response; meanwhile, the development of chronic liver disease is correlated with a weak antiviral immune response, as previously mentioned. In addition to the genetic background of the infected host, there are questions that might be resolved in relation to immune response and viral factors, such as (a) what is the role of HBV variability in the clearance or persistence of the infection? (b) Why do some patients with HBV BCP and/or pre-core mutations develop HCC, and other patients carrying the same HBV mutations are asymptomatic or just have mild liver disease? For example, patients infected with genotype $\mathrm{H}$ and these mutations are at risk to develop HCC? (c) Is genotype H really associated with mild liver disease? No data are focused on this topic, possibly because most of the patients infected with genotype $\mathrm{H}$ are living in low-income areas from Mexico, and it is possible that they die before HCC development due to liver cirrhosis complications. It must be relevant to perform longitudinal studies in countries where genotypes F, G, E and H are prevalent in order to increase the knowledge about their association with the natural history of hepatitis B. Moreover, research must go on since HBV emergence mutations are continuously changing by the immune or treatment pressure and the virus's low capacity to repair its DNA mistakes. These deficiencies could be overcome by taking more interest in the molecular diagnosis of the infection and improving the strategies for the follow-up of patients. Hence, the obtained results would impact translational medicine.

Chronic hepatitis B stages can be well identified by biochemical and viral markers (e.g., ALT, AST, viral load, etc.), while NK and T cells seem to suffer changes in their activity during the disease progression, according to the disease stages (changes in their phenotypes and production of cytokines). These changes could be generated by the induced tolerant state caused by the expression of inhibitory receptors and the secretion of regulatory cytokines such as IL-10. In addition, TGF- $\beta$, IL-22, and IL-17 cytokines are correlated with liver damage progression. It is possible that in the near future, these deregulated molecules could be used as liquid biopsy improving the earlier diagnosis of HBV infection or identifying the chronic stages of liver disease in order to detect more accurate predictors of treatment response.

A relevant issue of interest in the overall research on chronic hepatitis B is the "strategies" employed by the virus to evade and block the antiviral response. These evasion 
mechanisms, such as diminishing the expression of TLRs and blocking of sensors and cellular signaling involved in the viral response, favor the infection persistence. Research must continue trying to identify efficient cccDNA inhibitors in order to reduce the HBV replication, transcription and antigens synthesis restoring the immune response with an efficient viral clearance.

Author Contributions: Planning, bibliographic revision, writing, original draft preparation, M.C.-V. and L.V.S.-O.; review, editing, and writing H.C.M.-R. and J.A.-B.; figures design, M.C.-V. All authors have read and agreed to the published version of the manuscript.

Funding: CUCS: Universidad de Guadalajara (APPAC-III, CUCS 2021). Campos-Valdez M. is part of the CONACYT doctoral fellowship program (Number 824914).

Conflicts of Interest: The authors declare no conflict of interest.

\section{References}

1. Schieck, A.; Schulze, A.; Gähler, C.; Müller, T.; Haberkorn, U.; Alexandrov, A.; Urban, S.; Mier, W. Hepatitis B virus hepatotropism is mediated by specific receptor recognition in the liver and not restricted to susceptible hosts. Hepatology 2013, 58, 43-53. [CrossRef] [PubMed]

2. Patient, R.; Hourioux, C.; Roingeard, P. Morphogenesis of hepatitis B virus and its subviral envelope particles. Cell. Microbiol. 2009, 11, 1561-1570. [CrossRef]

3. Pastor, F.; Herrscher, C.; Patient, R.; Eymieux, S.; Moreau, A.; Burlaud-Gaillard, J.; Seigneuret, F.; De Rocquigny, H.; Roingeard, P.; Hourioux, C. Direct interaction between the hepatitis B virus core and envelope proteins analyzed in a cellular context. Sci. Rep. 2019, 9, 1-12. [CrossRef] [PubMed]

4. Karayiannis, P. Hepatitis B virus: Virology, molecular biology, life cycle and intrahepatic spread. Hepatol. Int. 2017, 11, 500-508. [CrossRef]

5. McNaughton, A.L.; D'Arienzo, V.; Ansari, M.A.; Lumley, S.; Littlejohn, M.; Revill, P.; McKeating, J.A.; Matthews, P.C. Insights From Deep Sequencing of the HBV Genome-Unique, Tiny, and Misunderstood. Gastroenterology 2019, 156, 384-399. [CrossRef]

6. Li, S.; Wang, Z.; Li, Y.; Ding, G. Adaptive evolution of proteins in hepatitis B virus during divergence of genotypes. Sci. Rep. 2017, 7, 1-11. [CrossRef] [PubMed]

7. Harrison, A.; Lemey, P.; Hurles, M.; Moyes, C.; Horn, S.; Pryor, J.; Malani, J.; Supuri, M.; Masta, A.; Teriboriki, B.; et al. Genomic Analysis of Hepatitis B Virus Reveals Antigen State and Genotype as Sources of Evolutionary Rate Variation. Viruses 2011, 3, 83-101. [CrossRef]

8. Caligiuri, P.; Cerruti, R.; Icardi, G.; Bruzzone, B. Overview of hepatitis B virus mutations and their implications in the management of infection. World J. Gastroenterol. 2016, 22, 145-154. [CrossRef] [PubMed]

9. Araujo, N.M.; Teles, S.A.; Spitz, N. Comprehensive Analysis of Clinically Significant Hepatitis B Virus Mutations in Relation to Genotype, Subgenotype and Geographic Region. Front. Microbiol. 2020, 11, 11. [CrossRef]

10. Chen, P.; Gan, Y.; Han, N.; Fang, W.; Li, J.; Zhao, F.; Hu, K.; Rayner, S. Computational Evolutionary Analysis of the Overlapped Surface (S) and Polymerase (P) Region in Hepatitis B Virus Indicates the Spacer Domain in P Is Crucial for Survival. PLoS ONE 2013, 8, e60098. [CrossRef]

11. Zhang, D.; Chen, J.; Deng, L.; Mao, Q.; Zheng, J.; Wu, J.; Zeng, C.; Li, Y. Evolutionary selection associated with the multi-function of overlapping genes in the hepatitis B virus. Infect. Genet. Evol. 2010, 10, 84-88. [CrossRef] [PubMed]

12. Casillas, R.; Tabernero, D.; Gregori, J.; Belmonte, I.; Cortese, M.F.; Gonzalez-Fernandez, C.; Riveiro-Barciela, M.; López, R.M.; Quer, J.; Esteban, R.; et al. Analysis of hepatitis B virus preS1 variability and prevalence of the rs2296651 polymorphism in a Spanish population. World J. Gastroenterol. 2018, 24, 680-692. [CrossRef] [PubMed]

13. Huang, H.-C.; Chen, C.-C.; Chang, W.-C.; Tao, M.-H.; Huang, C. Entry of Hepatitis B Virus into Immortalized Human Primary Hepatocytes by Clathrin-Dependent Endocytosis. J. Virol. 2012, 86, 9443-9453. [CrossRef]

14. Mitra, B.; Thapa, R.J.; Guo, H.; Block, T.M. Host functions used by hepatitis B virus to complete its life cycle: Implications for developing host-targeting agents to treat chronic hepatitis B. Antivir. Res. 2018, 158, 185-198. [CrossRef]

15. Gallucci, L.; Kann, M. Nuclear Import of Hepatitis B Virus Capsids and Genome. Viruses 2017, 9, 21. [CrossRef]

16. Yuen, M.-F.; Chen, D.-S.; Dusheiko, G.M.; Janssen, H.L.A.; Lau, D.T.Y.; Locarnini, S.A.; Peters, M.G.; Lai, C.-L. Hepatitis B virus infection. Nat. Rev. Dis. Prim. 2018, 4, 18035. [CrossRef] [PubMed]

17. Tu, T.; Budzinska, M.A.; Shackel, N.A.; Urban, S. HBV DNA Integration: Molecular Mechanisms and Clinical Implications. Viruses 2017, 9, 75. [CrossRef]

18. Wu, Y.; Wen, J.; Xiao, W.; Zhang, B. Pregenomic RNA: How to assist the management of chronic hepatitis B? Rev. Med. Virol. 2019, 29, e2051. [CrossRef]

19. Revill, P.A.; Tu, T.; Netter, H.J.; Yuen, L.K.W.; Locarnini, S.A.; Littlejohn, M. The evolution and clinical impact of hepatitis B virus genome diversity. Nat. Rev. Gastroenterol. Hepatol. 2020, 17, 618-634. [CrossRef] 
20. Pourkarim, M.R.; Amini-Bavil-Olyaee, S.; Kurbanov, F.; Van Ranst, M.; Tacke, F. Molecular identification of hepatitis B virus genotypes/subgenotypes: Revised classification hurdles and updated resolutions. World J. Gastroenterol. 2014, 20, 7152-7168. [CrossRef]

21. Kramvis, A. Genotypes and Genetic Variability of Hepatitis B Virus. Intervirology 2014, 57, 141-150. [CrossRef]

22. Schaefer, S. Hepatitis B virus taxonomy and hepatitis B virus genotypes. World J. Gastroenterol. 2007, 13, 14-21. [CrossRef] [PubMed]

23. Velkov, S.; Protzer, U.; Michler, T. Global Occurrence of Clinically Relevant Hepatitis B Virus Variants as Found by Analysis of Publicly Available Sequencing Data. Viruses 2020, 12, 1344. [CrossRef]

24. Sunbul, M. Hepatitis B virus genotypes: Global distribution and clinical importance. World J. Gastroenterol. 2014, 20, 5427-5434. [CrossRef] [PubMed]

25. Lin, C.-L.; Kao, J.-H. Hepatitis B Virus Genotypes and Variants. Cold Spring Harb. Perspect. Med. 2015, 5, a021436. [CrossRef]

26. Croagh, C.M.; Desmond, P.V.; Bell, S.J. Genotypes and viral variants in chronic hepatitis B: A review of epidemiology and clinical relevance. World J. Hepatol. 2015, 7, 289-303. [CrossRef] [PubMed]

27. Sánchez-Tapias, J.M.; Costa, J.; Mas, A.; Bruguera, M.; Rodés, J. Influence of hepatitis B virus genotype on the long-term outcome of chronic hepatitis B in western patients. Gastroenterology 2002, 123, 1848-1856. [CrossRef] [PubMed]

28. Ito, K.; Yotsuyanagi, H.; Yatsuhashi, H.; Karino, Y.; Takikawa, Y.; Saito, T.; Arase, Y.; Imazeki, F.; Kurosaki, M.; Umemura, T.; et al. Risk factors for long-term persistence of serum hepatitis B surface antigen following acute hepatitis B virus infection in Japanese adults. Hepatology 2014, 59, 89-97. [CrossRef]

29. Zhang, H.W.; Yin, J.H.; Li, Y.T.; Li, C.Z.; Ren, H.; Gu, C.Y.; Wu, H.Y.; Liang, X.S.; Zhang, P.; Zhao, J.F.; et al. Risk factors for acute hepatitis B and its progression to chronic hepatitis in Shanghai, China. Gut 2008, 57, 1713-1720. [CrossRef]

30. Wai, C.-T.; Fontana, R.J.; Polson, J.; Hussain, M.; Shakil, A.O.; Han, S.-H.; Davern, T.J.; Lee, W.M.; Lok, A.S.-F.; The US Acute Liver Failure Study Group. Clinical outcome and virological characteristics of hepatitis B-related acute liver failure in the United States. J. Viral Hepat. 2005, 12, 192-198. [CrossRef] [PubMed]

31. Roman, S. HBV endemicity in Mexico is associated with HBV genotypes H and G. World J. Gastroenterol. 2013, 19, 5446-5453. [CrossRef]

32. Panduro, A.; Maldonado-González, M.; Fierro, N.A.; Roman, S. Distribution of HBV genotypes F and H in Mexico and Central America. Antivir. Ther. 2013, 18, 475-484. [CrossRef]

33. Fung, J.; Lai, C.-L.; Seto, W.-K.; Yuen, M.-F. Nucleoside/nucleotide analogues in the treatment of chronic hepatitis B. J. Antimicrob. Chemother. 2011, 66, 2715-2725. [CrossRef] [PubMed]

34. Menéndez-Arias, L.; Álvarez, M.; Pacheco, B. Nucleoside/nucleotide analog inhibitors of hepatitis B virus polymerase: Mechanism of action and resistance. Curr. Opin. Virol. 2014, 8, 1-9. [CrossRef] [PubMed]

35. Amini-Bavil-Olyaee, S.; Herbers, U.; Sheldon, J.; Luedde, T.; Trautwein, C.; Tacke, F. The rtA194T polymerase mutation impacts viral replication and susceptibility to tenofovir in hepatitis B e antigen-positive and hepatitis B e antigen-negative hepatitis B virus strains. Hepatology 2008, 49, 1158-1165. [CrossRef]

36. Thai, H.; Lara, J.; Xu, X.; Kitrinos, K.; Gaggar, A.; Chan, H.L.Y.; Xia, G.-L.; Ganova-Raeva, L.; Khudyakov, Y. Complex genetic encoding of the hepatitis B virus on-drug persistence. Sci. Rep. 2020, 10, 1-13. [CrossRef]

37. Cento, V.; Mirabelli, C.; Dimonte, S.; Salpini, R.; Han, Y.; Trimoulet, P.; Bertoli, A.; Micheli, V.; Gubertini, G.; Cappiello, G.; et al. Overlapping structure of hepatitis B virus (HBV) genome and immune selection pressure are critical forces modulating HBV evolution. J. Gen. Virol. 2013, 94, 143-149. [CrossRef] [PubMed]

38. Su, M.; Xiang, K.; Li, Y.; Li, Y.; Deng, J.; Xu, X.; Yan, L.; Zhuang, H.; Li, T. Higher detection rates of amino acid substitutions in HBV reverse transcriptase/surface protein overlapping sequence is correlated with lower serum HBV DNA and HBsAg levels in HBeAg-positive chronic hepatitis B patients with subgenotype B2. Infect. Genet. Evol. 2016, 40, 275-281. [CrossRef]

39. Monto, A.; Schooley, R.T.; Lai, J.C.; Sulkowski, M.S.; Chung, R.T.; Pawlotsky, J.-M.; McHutchison, J.G.; Jacobson, I.M. Lessons From HIV Therapy Applied to Viral Hepatitis Therapy: Summary of a Workshop. Am. J. Gastroenterol. 2010, 105, 989-1004. [CrossRef]

40. Tseng, T.-C.; Liu, C.; Yang, H.; Su, T.; Wang, C.; Chen, C.; Kuo, S.F.; Liu, C.; Chen, P.; Chen, D.-S.; et al. High Levels of Hepatitis B Surface Antigen Increase Risk of Hepatocellular Carcinoma in Patients with Low HBV Load. Gastroenterology 2012, 142, 1140-1149.e3. [CrossRef]

41. Sarma, M.P.; Bhattacharjee, M.; Kar, P.; Medhi, S. Detection of HBV Genotype C in Hepatocellular Carcinoma Patients from North East India: A Brief Report. Asian Pac. J. Cancer Prev. 2018, 19, 1741-1746.

42. Asim, M.; Sarma, M.P.; Kar, P. Etiological and molecular profile of hepatocellular cancer from India. Int. J. Cancer 2013, 133, 437-445. [CrossRef]

43. Datta, S.; Dasgupta, D.; Ghosh, A.; Ghosh, S.; Manna, A.; Datta, S.; Chatterjee, M.; Chowdhury, A.; Banerjee, S. Oncogenic potential of hepatitis B virus subgenotype D1 surpasses D3: Significance in the development of hepatocellular carcinoma. Carcinogenesis 2018, 39, 283-292. [CrossRef] [PubMed]

44. Yu, M.-W.; Yeh, S.-H.; Chen, P.-J.; Liaw, Y.-F.; Lin, C.-L.; Liu, C.-J.; Shih, W.-L.; Kao, J.-H.; Chen, D.-S.; Chen, C.-J. Hepatitis B Virus Genotype and DNA Level and Hepatocellular Carcinoma: A Prospective Study in Men. J. Natl. Cancer Inst. 2005, 97, 265-272. [CrossRef]

45. Yang, H.-I.; Yeh, S.-H.; Chen, P.-J.; Iloeje, U.H.; Jen, C.-L.; Su, J.; Wang, L.-Y.; Lu, S.-N.; You, S.-L.; Chen, D.-S.; et al. Associations Between Hepatitis B Virus Genotype and Mutants and the Risk of Hepatocellular Carcinoma. J. Natl. Cancer Inst. 2008, 100, 1134-1143. [CrossRef] [PubMed] 
46. Inoue, J.; Akahane, T.; Nakayama, H.; Kimura, O.; Kobayashi, T.; Kisara, N.; Sato, T.; Morosawa, T.; Izuma, M.; Kakazu, E.; et al. Comparison of hepatitis B virus genotypes B and C among chronically hepatitis B virus-infected patients who received nucleos(t)ide analogs: A multicenter retrospective study. Hepatol. Res. 2019, 49, 1263-1274. [CrossRef] [PubMed]

47. Kao, J.; Chen, P.; Lai, M.; Chen, D.-S. Basal core promoter mutations of hepatitis B virus increase the risk of hepatocellular carcinoma in hepatitis B carriers. Gastroenterology 2003, 124, 327-334. [CrossRef] [PubMed]

48. Lau, K.C.; Burak, K.W.; Coffin, C.S. Impact of Hepatitis B Virus Genetic Variation, Integration, and Lymphotropism in Antiviral Treatment and Oncogenesis. Microorganisms 2020, 8, 1470. [CrossRef]

49. Livingston, S.E.; Simonetti, J.P.; McMahon, B.J.; Bulkow, L.R.; Hurlburt, K.J.; Homan, C.E.; Snowball, M.M.; Cagle, H.H.; Williams, J.L.; Chulanov, V.P. Hepatitis B Virus Genotypes in Alaska Native People with Hepatocellular Carcinoma: Preponderance of Genotype F. J. Infect. Dis. 2007, 195, 5-11. [CrossRef] [PubMed]

50. Teng, C.-F.; Li, T.-C.; Huang, H.-Y.; Lin, J.-H.; Chen, W.-S.; Shyu, W.-C.; Wu, H.-C.; Peng, C.-Y.; Su, I.-J.; Jeng, L.-B. Next-Generation Sequencing-Based Quantitative Detection of Hepatitis B Virus Pre-S Mutants in Plasma Predicts Hepatocellular Carcinoma Recurrence. Viruses 2020, 12, 796. [CrossRef]

51. Takahashi, K.; Akahane, Y.; Hino, K.; Ohta, Y.; Mishiro, S. Hepatitis B virus genomic sequence in the circulation of hepatocellular carcinoma patients: Comparative analysis of 40 full-length isolates. Arch. Virol. 1998, 143, 2313-2326. [CrossRef]

52. Li, Y.; Xia, Y.; Cheng, X.; Kleiner, D.E.; Hewitt, S.M.; Sproch, J.; Li, T.; Zhuang, H.; Liang, T.J. Hepatitis B Surface Antigen Activates Unfolded Protein Response in Forming Ground Glass Hepatocytes of Chronic Hepatitis B. Viruses 2019, 11, 386. [CrossRef]

53. Tsai, H.-W.; Lin, Y.-J.; Lin, P.-W.; Wu, H.-C.; Hsu, K.-H.; Yen, C.-J.; Chan, S.-H.; Huang, W.; Su, I.-J. A clustered ground-glass hepatocyte pattern represents a new prognostic marker for the recurrence of hepatocellular carcinoma after surgery. Cancer 2011, 117, 2951-2960. [CrossRef]

54. Wang, H.-C.; Huang, W.; Lai, M.-D.; Su, I.-J. Hepatitis B virus pre-S mutants, endoplasmic reticulum stress and hepatocarcinogenesis. Cancer Sci. 2006, 97, 683-688. [CrossRef] [PubMed]

55. Su, I.-J.; Wang, H.-C.; Wu, H.-C.; Huang, W.-Y. Ground glass hepatocytes contain pre-S mutants and represent preneoplastic lesions in chronic hepatitis B virus infection. J. Gastroenterol. Hepatol. 2008, 23, 1169-1174. [CrossRef] [PubMed]

56. Teng, C.-F.; Wu, H.-C.; Su, I.-J.; Jeng, L.-B. Hepatitis B Virus Pre-S Mutants as Biomarkers and Targets for the Development and Recurrence of Hepatocellular Carcinoma. Viruses 2020, 12, 945. [CrossRef] [PubMed]

57. Lin, Y.-T.; Jeng, L.-B.; Chan, W.-L.; Su, I.-J.; Teng, C.-F. Hepatitis B Virus Pre-S Gene Deletions and Pre-S Deleted Proteins: Clinical and Molecular Implications in Hepatocellular Carcinoma. Viruses 2021, 13, 862. [CrossRef] [PubMed]

58. Wang, H.-C.; Wu, H.-C.; Chen, C.-F.; Fausto, N.; Lei, H.-Y.; Su, I.-J. Different Types of Ground Glass Hepatocytes in Chronic Hepatitis B Virus Infection Contain Specific Pre-S Mutants that May Induce Endoplasmic Reticulum Stress. Am. J. Pathol. 2003, 163, 2441-2449. [CrossRef]

59. Su, I.-J.; Wang, L.H.-C.; Hsieh, W.-C.; Wu, H.-C.; Teng, C.-F.; Tsai, H.-W.; Huang, W. The emerging role of hepatitis B virus Pre-S2 deletion mutant proteins in HBV tumorigenesis. J. Biomed. Sci. 2014, 21, 1-8. [CrossRef]

60. Mathai, A.M.; Alexander, J.; Kuo, F.-Y.; Torbenson, M.; Swanson, P.; Yeh, M.M. Type II ground-glass hepatocytes as a marker of hepatocellular carcinoma in chronic hepatitis B. Hum. Pathol. 2013, 44, 1665-1671. [CrossRef] [PubMed]

61. World Health Organization. Hepatitis B. Available online: https://www.who.int/news-room/fact-sheets/detail/hepatitis-b (accessed on 20 May 2021).

62. WHO. Who Global Hepatitis Report; WHO: Geneva, Switzerland, 2017; ISBN 9789241565455.

63. Komatsu, H.; Inui, A.; Sogo, T.; Tateno, A.; Shimokawa, R.; Fujisawa, T. Tears from Children with Chronic Hepatitis B Virus (HBV) Infection Are Infectious Vehicles of HBV Transmission: Experimental Transmission of HBV by Tears, Using Mice with Chimeric Human Livers. J. Infect. Dis. 2012, 206, 478-485. [CrossRef]

64. Kidd-Ljunggren, K.; Holmberg, A.; Bläckberg, J.; Lindqvist, B. High levels of hepatitis B virus DNA in body fluids from chronic carriers. J. Hosp. Infect. 2006, 64, 352-357. [CrossRef]

65. Heiberg, I.L.; Hoegh, M.; Ladelund, S.; Niesters, H.; Hogh, B. Hepatitis B Virus DNA in Saliva from Children with Chronic Hepatitis B Infection: Implications for Saliva as a Potential Mode of Horizontal Transmission. Pediatr. Infect. Dis. J. 2010, 29, 465-467. [CrossRef]

66. Bereket-Yucel, S.; Konukman, F. Risk of hepatitis B infections in Olympic wrestling. Br. J. Sports Med. 2007, 41, 306-310. [CrossRef] [PubMed]

67. Van Der Eijk, A.A.; Niesters, H.; Hansen, B.; Pas, S.D.; Richardus, J.H.; Mostert, M.; Janssen, H.L.; Schalm, S.W.; De Man, R.A. Paired, quantitative measurements of hepatitis B virus DNA in saliva, urine and serum of chronic hepatitis B patients. Eur. J. Gastroenterol. Hepatol. 2005, 17, 1173-1179. [CrossRef] [PubMed]

68. Heiberg, I.L.; Hogh, B. Horizontal transmission of hepatitis B virus-why discuss when we can vaccinate? J. Infect. Dis. 2012, 206, 464-465. [CrossRef] [PubMed]

69. Burns, G.S.; Thompson, A.J. Viral Hepatitis B: Clinical and Epidemiological Characteristics. Cold Spring Harb. Perspect. Med. 2014, 4, a024935. [CrossRef]

70. Terrault, N.A.; Lok, A.S.; McMahon, B.J.; Chang, K.-M.; Hwang, J.; Jonas, M.M.; Brown, R.S., Jr.; Bzowej, N.H.; Wong, J.B. Update on prevention, diagnosis, and treatment of chronic hepatitis B: AASLD 2018 hepatitis B guidance. Hepatology 2018, 67, 1560-1599. [CrossRef] [PubMed] 
71. Beasley, R.P.; Hwang, L.-Y.; Lin, C.-C.; Leu, M.-L.; Stevens, C.E.; Szmuness, W.; Chen, K.-P. Incidence of Hepatitis B Virus Infections in Preschool Children in Taiwan. J. Infect. Dis. 1982, 146, 198-204. [CrossRef]

72. Coursaget, P.; Yvonnet, B.; Chotard, J.; Vincelot, P.; Sarr, M.; Diouf, C.; Chiron, J.P.; Diop-Mar, I. Age- and sex-related study of hepatitis B virus chronic carrier state in infants from an endemic area (Senegal). J. Med. Virol. 1987, 22, 1-5. [CrossRef]

73. Likhitsup, A.; Lok, A.S. Understanding the Natural History of Hepatitis B Virus Infection and the New Definitions of Cure and the Endpoints of Clinical Trials. Clin. Liver Dis. 2019, 23, 401-416. [CrossRef]

74. Rehermann, B.; Ferrari, C.; Pasquinelli, C.; Chisari, F. The hepatitis B virus persists for decades after patients' recovery from acute viral hepatitis despite active maintenance of a cytotoxic T-lymphocyte response. Nat. Med. 1996, 2, 1104-1108. [CrossRef] [PubMed]

75. Yuki, N.; Nagaoka, T.; Yamashiro, M.; Mochizuki, K.; Kaneko, A.; Yamamoto, K.; Omura, M.; Hikiji, K.; Kato, M. Long-term histologic and virologic outcomes of acute self-limited hepatitis B. Hepatology 2003, 37, 1172-1179. [CrossRef]

76. Ahn, S.H.; Park, Y.N.; Park, J.Y.; Chang, H.-Y.; Lee, J.M.; Shin, J.E.; Han, K.-H.; Park, C.; Moon, Y.M.; Chon, C.Y. Long-term clinical and histological outcomes in patients with spontaneous hepatitis B surface antigen seroclearance. J. Hepatol. 2005, 42, 188-194. [CrossRef]

77. Hsu, C.; Tsou, H.-H.; Lin, S.-J.; Wang, M.-C.; Yao, M.; Hwang, W.-L.; Kao, W.-Y.; Chiu, C.-F.; Lin, S.-F.; Lin, J.; et al. Chemotherapyinduced hepatitis B reactivation in lymphoma patients with resolved HBV infection: A prospective study. Hepatology 2013, 59, 2092-2100. [CrossRef]

78. Seto, W.-K.; Chan, T.S.-Y.; Hwang, Y.-Y.; Wong, D.K.-H.; Fung, J.; Liu, K.S.-H.; Gill, H.; Lam, Y.-F.; Lau, E.H.; Cheung, K.-S.; et al. Hepatitis B reactivation in occult viral carriers undergoing hematopoietic stem cell transplantation: A prospective study. Hepatology 2017, 65, 1451-1461. [CrossRef]

79. Mysore, K.R.; Leung, D.H. Hepatitis B and C. Clin. Liver Dis. 2018, 22, 703-722. [CrossRef]

80. Shouval, D.; Shibolet, O. Immunosuppression and HBV Reactivation. Semin. Liver Dis. 2013, 33, 167-177. [CrossRef] [PubMed]

81. Hoofnagle, J.H. Reactivation of hepatitis B. Hepatology 2009, 49, S156-S165. [CrossRef] [PubMed]

82. European Association for the Study of the Liver. EASL 2017 Clinical Practice Guidelines on the management of hepatitis B virus infection. J. Hepatol. 2017, 67, 370-398. [CrossRef] [PubMed]

83. Wang, W.-T.; Zhao, X.-Q.; Li, G.-P.; Chen, Y.-Z.; Wang, L.; Han, M.-F.; Li, W.-N.; Chen, T.; Chen, G.; Xu, N.; et al. Immune response pattern varies with the natural history of chronic hepatitis B. World J. Gastroenterol. 2019, 25, 1950-1963. [CrossRef]

84. Busca, A.; Kumar, A. Innate immune responses in hepatitis B virus (HBV) infection. Virol. J. 2014, 11, 22. [CrossRef]

85. Chisari, F.V. Hepatitis B virus transgenic mice: Models of viral immunobiology and pathogenesis. In Current Topics in Microbiology and Imunology; Oldstone, M.B.A., Ed.; Springer: Berlin/Heidelberg, Germany, 1996; Volume 206, pp. 149-173. ISBN 978-3-642-85208-4.

86. Tseng, T.-C.; Huang, L.-R. Immunopathogenesis of Hepatitis B Virus. J. Infect. Dis. 2017, 216, S765-S770. [CrossRef] [PubMed]

87. Fisicaro, P.; Valdatta, C.; Boni, C.; Massari, M.; Mori, C.; Zerbini, A.; Orlandini, A.; Sacchelli, L.; Missale, G.; Ferrari, C. Early kinetics of innate and adaptive immune responses during hepatitis B virus infection. Gut 2009, 58, 974-982. [CrossRef] [PubMed]

88. Dunn, C.; Peppa, D.; Khanna, P.; Nebbia, G.; Jones, M.; Brendish, N.; Lascar, R.M.; Brown, D.; Gilson, R.J.; Tedder, R.J.; et al. Temporal Analysis of Early Immune Responses in Patients with Acute Hepatitis B Virus Infection. Gastroenterology 2009, 137, 1289-1300. [CrossRef]

89. Webster, G.J.; Reignat, S.; Maini, M.; Whalley, S.A.; Ogg, G.S.; King, A.; Brown, D.; Amlot, P.L.; Williams, R.; Vergani, D.; et al. Incubation Phase of Acute Hepatitis B in Man: Dynamic of Cellular Immune Mechanisms. Hepatology 2000, 32, 1117-1124. [CrossRef]

90. Guidotti, L.G.; Ishikawa, T.; Hobbs, M.V.; Matzke, B.; Schreiber, R.; Chisari, F.V. Intracellular inactivation of the hepatitis B virus by cytotoxic T lymphocytes. Immunity 1996, 4, 25-36. [CrossRef]

91. Xia, Y.; Stadler, D.; Lucifora, J.; Reisinger, F.; Webb, D.; Hösel, M.; Michler, T.; Wisskirchen, K.; Cheng, X.; Zhang, K.; et al. Interferon- $\gamma$ and Tumor Necrosis Factor- $\alpha$ Produced by T Cells Reduce the HBV Persistence Form, cccDNA, Without Cytolysis. Gastroenterology 2016, 150, 194-205. [CrossRef]

92. Thimme, R.; Wieland, S.; Steiger, C.; Ghrayeb, J.; Reimann, K.A.; Purcell, R.H.; Chisari, F.V. CD8 + T Cells Mediate Viral Clearance and Disease Pathogenesis during Acute Hepatitis B Virus Infection. J. Virol. 2003, 77, 68-76. [CrossRef]

93. Ferrari, C.; Penna, A.; Bertoletti, A.; Valli, A.; Antoni, A.D.; Giuberti, T.; Cavalli, A.; Petit, M.A.; Fiaccadori, F. Cellular immune response to hepatitis B virus-encoded antigens in acute and chronic hepatitis B virus infection. J. Immunol. 1990, 145, 3442-3449.

94. Guidotti, L.G.; Rochford, R.; Chung, J.; Shapiro, M.; Purcell, R.; Chisari, F. Viral Clearance without Destruction of Infected Cells During Acute HBV Infection. Science 1999, 284, 825-829. [CrossRef] [PubMed]

95. Shin, E.-C.; Sung, P.S.; Park, S.-H. Immune responses and immunopathology in acute and chronic viral hepatitis. Nat. Rev. Immunol. 2016, 16, 509-523. [CrossRef] [PubMed]

96. Baron, J.L.; Gardiner, L.; Nishimura, S.; Shinkai, K.; Locksley, R.; Ganem, D. Activation of a Nonclassical NKT Cell Subset in a Transgenic Mouse Model of Hepatitis B Virus Infection. Immunity 2002, 16, 583-594. [CrossRef]

97. Sandhu, P.; Haque, M.; Humphries-Bickley, T.; Ravi, S.; Song, J. Hepatitis B Virus Immunopathology, Model Systems, and Current Therapies. Front. Immunol. 2017, 8, 436. [CrossRef]

98. Chisari, F.; Isogawa, M.; Wieland, S. Pathogenesis of hepatitis B virus infection. Pathol. Biol. 2010, 58, 258-266. [CrossRef] [PubMed]

99. Trépo, C.; Chan, H.L.Y.; Lok, A. Hepatitis B virus infection. Lancet 2014, 384, 2053-2063. [CrossRef] 
100. Stross, L.; Günther, J.; Gasteiger, G.; Asen, T.; Graf, S.; Aichler, M.; Esposito, I.; Busch, D.H.; Knolle, P.A.; Sparwasser, T.; et al. Foxp3+ regulatory $\mathrm{T}$ cells protect the liver from immune damage and compromise virus control during acute experimental hepatitis B virus infection in mice. Hepatology 2012, 56, 873-883. [CrossRef]

101. Suresh, M.; Czerwinski, S.; Murreddu, M.G.; Kallakury, B.V.; Ramesh, A.; Gudima, S.O.; Menne, S. Innate and adaptive immunity associated with resolution of acute woodchuck hepatitis virus infection in adult woodchucks. PLoS Pathog. 2019, 15, e1008248. [CrossRef]

102. Nassal, M. HBV cccDNA: Viral persistence reservoir and key obstacle for a cure of chronic hepatitis B. Gut 2015, 64, 1972-1984. [CrossRef] [PubMed]

103. Bengsch, B.; Martin, B.; Thimme, R. Restoration of HBV-specific CD8+ T cell function by PD-1 blockade in inactive carrier patients is linked to T cell differentiation. J. Hepatol. 2014, 61, 1212-1219. [CrossRef]

104. Fisicaro, P.; Valdatta, C.; Massari, M.; Loggi, E.; Biasini, E.; Sacchelli, L.; Cavallo, M.C.; Silini, E.M.; Andreone, P.; Missale, G.; et al. Antiviral Intrahepatic T-Cell Responses Can Be Restored by Blocking Programmed Death-1 Pathway in Chronic Hepatitis B. Gastroenterol. 2010, 138, 682-693. [CrossRef]

105. Schurich, A.; Khanna, P.; Lopes, A.R.; Han, K.J.; Peppa, D.; Micco, L.; Nebbia, G.; Kennedy, P.T.; Geretti, A.-M.; Dusheiko, G.; et al. Role of the coinhibitory receptor cytotoxic T lymphocyte antigen-4 on apoptosis-Prone CD8 T cells in persistent hepatitis B virus infection. Hepatology 2011, 53, 1494-1503. [CrossRef] [PubMed]

106. Nebbia, G.; Peppa, D.; Schurich, A.; Khanna, P.; Singh, H.D.; Cheng, Y.; Rosenberg, W.; Dusheiko, G.; Gilson, R.; ChinAleong, J.; et al. Upregulation of the Tim-3/Galectin-9 Pathway of T Cell Exhaustion in Chronic Hepatitis B Virus Infection. PLOS ONE 2012, 7, e47648. [CrossRef]

107. Raziorrouh, B.; Schraut, W.; Gerlach, T.; Nowack, D.; Grüner, N.H.; Ulsenheimer, A.; Zachoval, R.; Wächtler, M.; Spannagl, M.; Haas, J.; et al. The immunoregulatory role of CD244 in chronic hepatitis B infection and its inhibitory potential on virus-specific CD8 ${ }^{+}$T-cell function. Hepatology 2010, 52, 1934-1947. [CrossRef] [PubMed]

108. Ye, B.; Liu, X.; Li, X.; Kong, H.; Tian, L.; Chen, Y. T-cell exhaustion in chronic hepatitis B infection: Current knowledge and clinical significance. Cell Death Dis. 2015, 6, e1694. [CrossRef] [PubMed]

109. Stoop, J.N.; Van Der Molen, R.G.; Baan, C.C.; van der Laan, L.; Kuipers, E.J.; Kusters, J.G.; Janssen, H.L.A. Regulatory T cells contribute to the impaired immune response in patients with chronic hepatitis B virus infection. Hepatology 2005, 41, 771-778. [CrossRef]

110. Park, J.-J.; Wong, D.K.; Wahed, A.; Lee, W.M.; Feld, J.J.; Terrault, N.; Khalili, M.; Sterling, R.K.; Kowdley, K.V.; Bzowej, N.; et al. Hepatitis B Virus-Specific and Global T-Cell Dysfunction in Chronic Hepatitis B. Gastroenterology 2016, 150, 684-695.e5. [CrossRef]

111. Lopes, A.R.; Kellam, P.; Das, A.; Dunn, C.; Kwan, A.; Turner, J.; Peppa, D.; Gilson, R.J.; Gehring, A.; Bertoletti, A.; et al. Bim-mediated deletion of antigen-specific CD8+ T cells in patients unable to control HBV infection. J. Clin. Investig. 2008, 118, 1835-1845. [CrossRef]

112. Peppa, D.; Gill, U.S.; Reynolds, G.; Easom, N.J.; Pallett, L.J.; Schurich, A.; Micco, L.; Nebbia, G.; Singh, H.D.; Adams, D.; et al. Up-regulation of a death receptor renders antiviral T cells susceptible to NK cell-mediated deletion. J. Exp. Med. 2013, 210, 99-114. [CrossRef]

113. Oliviero, B.; Varchetta, S.; Paudice, E.; Michelone, G.; Zaramella, M.; Mavilio, D.; De Filippi, F.; Bruno, S.; Mondelli, M. Natural Killer Cell Functional Dichotomy in Chronic Hepatitis B and Chronic Hepatitis C Virus Infections. Gastroenterology 2009, 137, 1151-1160.e7. [CrossRef]

114. Peppa, D.; Micco, L.; Javaid, A.; Kennedy, P.T.F.; Schurich, A.; Dunn, C.; Pallant, C.; Ellis, G.; Khanna, P.; Dusheiko, G.; et al. Blockade of Immunosuppressive Cytokines Restores NK Cell Antiviral Function in Chronic Hepatitis B Virus Infection. PLoS Pathog. 2010, 6, e1001227. [CrossRef]

115. Sun, C.; Fu, B.; Gao, Y.; Liao, X.; Sun, R.; Tian, Z.; Wei, H. TGF- $\beta 1$ Down-Regulation of NKG2D/DAP10 and 2B4/SAP Expression on Human NK Cells Contributes to HBV Persistence. PLoS Pathog. 2012, 8, e1002594. [CrossRef]

116. Van Der Molen, R.G.; Sprengers, D.; Binda, R.S.; De Jong, E.C.; Niesters, H.; Kusters, J.G.; Kwekkeboom, J.; Janssen, H.L.A. Functional impairment of myeloid and plasmacytoid dendritic cells of patients with chronic hepatitis B. Hepatology 2004, 40, 738-746. [CrossRef]

117. Pallett, L.J.; Gill, U.S.; Quaglia, A.; Sinclair, L.V.; Jover-Cobos, M.; Schurich, A.; Singh, K.P.; Thomas, N.; Das, A.; Chen, A.; et al. Metabolic regulation of hepatitis B immunopathology by myeloid-derived suppressor cells. Nat. Med. 2015, 21, 591-600. [CrossRef]

118. Tian, Y.; Kuo, C.-F.; Akbari, O.; Ou, J.-H.J. Maternal-Derived Hepatitis B Virus e Antigen Alters Macrophage Function in Offspring to Drive Viral Persistence after Vertical Transmission. Immunity 2016, 44, 1204-1214. [CrossRef]

119. Zeng, Z.; Li, L.; Chen, Y.; Wei, H.; Sun, R.; Tian, Z. Interferon- $\gamma$ facilitates hepatic antiviral T cell retention for the maintenance of liver-induced systemic tolerance. J. Exp. Med. 2016, 213, 1079-1093. [CrossRef] [PubMed]

120. Zhao, J.; Zhang, Z.; Luan, Y.; Zou, Z.; Sun, Y.; Li, Y.; Jin, L.; Zhou, C.; Fu, J.; Gao, B.; et al. Pathological functions of interleukin-22 in chronic liver inflammation and fibrosis with hepatitis B virus infection by promoting T helper 17 cell recruitment. Hepatology 2014, 59, 1331-1342. [CrossRef] [PubMed]

121. Sun, H.Q.; Zhang, J.Y.; Zhang, H.; Zou, Z.S.; Wang, F.S.; Jia, J.H. Increased Th17 cells contribute to disease progression in patients with HBV-associated liver cirrhosis. J. Viral Hepat. 2012, 19, 396-403. [CrossRef] [PubMed] 
122. Oketani, M.; Uto, H.; Ido, A.; Tsubouchi, H. Management of hepatitis B virus-related acute liver failure. Clin. J. Gastroenterol. 2014, 7, 19-26. [CrossRef] [PubMed]

123. Ichai, P.; Samuel, D. Management of Fulminant Hepatitis B. Curr. Infect. Dis. Rep. 2019, 21, 25. [CrossRef]

124. Hughes, S.A.; Wedemeyer, H.; Harrison, P.M. Hepatitis delta virus. Lancet 2011, 378, 73-85. [CrossRef]

125. Kusakabe, A.; Tanaka, Y.; Mochida, S.; Nakayama, N.; Inoue, K.; Sata, M.; Isoda, N.; Kang, J.H.; Sumino, Y.; Yatsuhashi, H.; et al. Case-control study for the identification of virological factors associated with fulminant hepatitis B. Hepatol. Res. 2009, 39, 648-656. [CrossRef]

126. Chen, Z.; Diaz, G.; Pollicino, T.; Zhao, H.; Engle, R.E.; Schuck, P.; Shen, C.-H.; Zamboni, F.; Long, Z.; Kabat, J.; et al. Role of humoral immunity against hepatitis B virus core antigen in the pathogenesis of acute liver failure. PNAS 2018, 115, E11369-E11378. [CrossRef] [PubMed]

127. Shen, C.; Yan, W.-Z.; Zhao, C.-Y.; Che, H.-H.; Liu, X.-Y.; Liu, Z.-Z.; Wang, Y.-D.; Wang, W.; Li, M.; Gao, J. Increased CD4+CD25+ regulatory $\mathrm{T}$ cells correlate with poor short-term outcomes in hepatitis B virus-related acute-on-chronic liver failure patients. $J$. Microbiol. Immunol. Infect. 2015, 48, 137-146. [CrossRef]

128. Wang, K.; Wu, Z.-B.; Ye, Y.-N.; Liu, J.; Zhang, G.-L.; Su, Y.-J.; He, H.-L.; Zheng, Y.-B.; Gao, Z.-L. Plasma Interleukin-10: A Likely Predictive Marker for Hepatitis B Virus-Related Acute-on-Chronic Liver Failure. Hepat. Mon. 2014, 14, e19370. [CrossRef]

129. Liu, G.; Tang, K.; Li, Q.; Yuan, G.; Cao, W.; Lu, W. Changes of IL-1, TNF-Alpha, IL-12 and IL-10 Levels with Chronic Liver Failure. Surg. Sci. 2011, 2, 69-72. [CrossRef]

130. Mourtzikou, A.; Alepaki, M.; Stamouli, M.; Pouliakis, A.; Skliris, A.; Karakitsos, P. Evaluation of serum levels of IL-6, TNF- $\alpha$, IL-10, IL-2 and IL-4 in patients with chronic hepatitis. Inmunología 2014, 33, 41-50. [CrossRef]

131. Song, L.H.; Binh, V.Q.; Duy, D.N.; Kun, J.F.; Bock, T.C.; Kremsner, P.G.; Luty, A. Serum cytokine profiles associated with clinical presentation in Vietnamese infected with hepatitis B virus. J. Clin. Virol. 2003, 28, 93-103. [CrossRef]

132. Falasca, K.; Ucciferri, C.; Dalessandro, M.; Zingariello, P.; Mancino, P.; Petrarca, C.; Pizzigallo, E.; Conti, P.; Vecchiet, J. Cytokine patterns correlate with liver damage in patients with chronic hepatitis B and C. Ann. Clin. Lab. Sci. 2006, 36, 144-150.

133. Poovorawan, K.; Tangkijvanich, P.; Chirathaworn, C.; Wisedopas, N.; Treeprasertsuk, S.; Komolmit, P.; Poovorawan, Y. Circulating Cytokines and Histological Liver Damage in Chronic Hepatitis B Infection. Hepat. Res. Treat. 2013, 2013, 1-7. [CrossRef]

134. Ming, D.; Yu, X.; Guo, R.; Deng, Y.; Li, J.; Lin, C.; Su, M.; Lin, Z.; Su, Z. Elevated TGF- $\beta 1 /$ IL-31 Pathway Is Associated with the Disease Severity of Hepatitis B Virus-Related Liver Cirrhosis. Viral Immunol. 2015, 28, 209-216. [CrossRef]

135. Yu, X.; Guo, R.; Ming, D.; Deng, Y.; Su, M.; Lin, C.; Li, J.; Lin, Z.; Su, Z. The Transforming Growth Factor $\beta 1 /$ Interleukin-31 Pathway Is Upregulated in Patients with Hepatitis B Virus-Related Acute-on-Chronic Liver Failure and Is Associated with Disease Severity and Survival. Clin. Vaccine Immunol. 2015, 22, 484-492. [CrossRef] [PubMed]

136. Ni, S.; Li, S.; Yang, N.; Tang, X.; Zhang, S.; Hu, D.; Lu, M. Deregulation of Regulatory T Cells in Acute-on-Chronic Liver Failure: A Rat Model. Mediat. Inflamm. 2017, 2017, 1-10. [CrossRef]

137. Zhang, G.-L.; Xie, D.-Y.; Lin, B.-L.; Xie, C.; Ye, Y.-N.; Peng, L.; Zhang, S.-Q.; Zhang, Y.-F.; Lai, Q.; Zhu, J.-Y.; et al. Imbalance of interleukin-17-producing CD4 T cells/regulatory T cells axis occurs in remission stage of patients with hepatitis B virus-related acute-on-chronic liver failure. J. Gastroenterol. Hepatol. 2013, 28, 513-521. [CrossRef]

138. Liang, X.-S.; Li, C.-Z.; Zhou, Y.; Yin, W.; Liu, Y.-Y.; Fan, W.-H. Changes in circulating Foxp3+regulatory T cells and interleukin-17producing T helper cells during HBV-related acute-on-chronic liver failure. World J. Gastroenterol. 2014, 20, 8558-8571. [CrossRef]

139. Niu, Y.-H.; Yin, D.-L.; Liu, H.-L.; Yi, R.-T.; Yang, Y.-C.; Xue, H.-A.; Chen, T.-Y.; Zhang, S.-L.; Lin, S.-M.; Zhao, Y.-R. Restoring the Treg cell to Th17 cell ratio may alleviate HBV-related acute-on-chronic liver failure. World J. Gastroenterol. 2013, 19, 4146-4154. [CrossRef]

140. Hu, F.; Bi, S.; Yan, H.; Shi, Y.; Sheng, J. Associations between hepatitis B virus basal core promoter/pre-core region mutations and the risk of acute-on-chronic liver failure: A meta-analysis. Virol. J. 2015, 12, 87. [CrossRef] [PubMed]

141. Ren, X.; Xu, Z.; Liu, Y.; Li, X.; Bai, S.; Ding, N.; Zhong, Y.; Wang, L.; Mao, P.; Zoulim, F.; et al. Hepatitis B virus genotype and basal core promoter/precore mutations are associated with hepatitis B-related acute-on-chronic liver failure without pre-existing liver cirrhosis. J. Viral Hepat. 2010, 17, 887-895. [CrossRef] [PubMed]

142. Xiao, L.; Zhou, B.; Gao, H.; Ma, S.; Yang, G.; Xu, M.; Abbott, W.G.; Chen, J.; Sun, J.; Wang, Z.; et al. Hepatitis B virus genotype B with G1896A and A1762T/G1764A mutations is associated with hepatitis B related acute-on-chronic liver failure. J. Med. Virol. 2011, 83, 1544-1550. [CrossRef] [PubMed]

143. Yang, G.; Han, M.; Chen, F.; Xu, Y.; Chen, E.; Wang, X.; Liu, Y.; Sun, J.; Hou, J.; Ning, Q.; et al. Hepatitis B virus genotype B and mutations in basal core promoter and pre-core/core genes associated with acute-on-chronic liver failure: A multicenter cross-sectional study in China. Hepatol. Int. 2014, 8, 508-516. [CrossRef] [PubMed]

144. Yang, Z.-T.; Huang, S.-Y.; Chen, L.; Liu, F.; Cai, X.-H.; Guo-Qing, Z.; Wang, M.-J.; Han, Y.; Su-Yuan, H.; Jiang, J.-H.; et al. Characterization of Full-Length Genomes of Hepatitis B Virus Quasispecies in Sera of Patients at Different Phases of Infection. J. Clin. Microbiol. 2015, 53, 2203-2214. [CrossRef]

145. Ma, Z.; Cao, Q.; Xiong, Y.; Zhang, E.; Lu, M. Interaction between Hepatitis B Virus and Toll-Like Receptors: Current Status and Potential Therapeutic Use for Chronic Hepatitis B. Vaccines 2018, 6, 6. [CrossRef]

146. Luangsay, S.; Ait-Goughoulte, M.; Michelet, M.; Floriot, O.; Bonnin, M.; Gruffaz, M.; Rivoire, M.; Fletcher, S.; Javanbakht, H.; Lucifora, J.; et al. Expression and functionality of Toll- and RIG-like receptors in HepaRG cells. J. Hepatol. 2015, 63, 1077-1085. [CrossRef] [PubMed] 
147. Lu, H.-L.; Liao, F. Melanoma Differentiation-Associated Gene 5 Senses Hepatitis B Virus and Activates Innate Immune Signaling To Suppress Virus Replication. J. Immunol. 2013, 191, 3264-3276. [CrossRef]

148. Sato, S.; Li, K.; Kameyama, T.; Hayashi, T.; Ishida, Y.; Murakami, S.; Watanabe, T.; Iijima, S.; Sakurai, Y.; Watashi, K.; et al. The RNA Sensor RIG-I Dually Functions as an Innate Sensor and Direct Antiviral Factor for Hepatitis B Virus. Immunity 2015, 42, 123-132. [CrossRef]

149. Luangsay, S.; Gruffaz, M.; Isorce, N.; Testoni, B.; Michelet, M.; Faure-Dupuy, S.; Maadadi, S.; Ait-Goughoulte, M.; Parent, R.; Rivoire, M.; et al. Early inhibition of hepatocyte innate responses by hepatitis B virus. J. Hepatol. 2015, 63, 1314-1322. [CrossRef]

150. Shlomai, A.; Schwartz, R.E.; Ramanan, V.; Bhatta, A.; de Jong, Y.P.; Bhatia, S.N.; Rice, C.M. Modeling host interactions with hepatitis B virus using primary and induced pluripotent stem cell-derived hepatocellular systems. PNAS 2014, 111, 12193-12198. [CrossRef]

151. Yang, Y.; Zhao, X.; Wang, Z.; Shu, W.; Li, L.; Li, Y.; Guo, Z.; Gao, B.; Xiong, S. Nuclear Sensor Interferon-Inducible Protein 16 Inhibits the Function of Hepatitis B Virus Covalently Closed Circular DNA by Integrating Innate Immune Activation and Epigenetic Suppression. Hepatology 2020, 71, 1154-1169. [CrossRef] [PubMed]

152. Lauterbach-Rivière, L.; Bergez, M.; Mönch, S.; Qu, B.; Riess, M.; Vondran, F.W.; Liese, J.; Hornung, V.; Urban, S.; König, R. Hepatitis B Virus DNA is a Substrate for the cGAS/STING Pathway but is not Sensed in Infected Hepatocytes. Viruses 2020, 12, 592. [CrossRef] [PubMed]

153. Breiner, K.M.; Schaller, H.; Knolle, P.A. Endothelial cell-mediated uptake of a hepatitis B virus: A new concept of liver targeting of hepatotropic microorganisms. Hepatology 2001, 34, 803-808. [CrossRef] [PubMed]

154. Ni, Y.; Li, J.-M.; Liu, M.-K.; Zhang, T.-T.; Wang, D.-P.; Zhou, W.-H.; Hu, L.-Z.; Lv, W.-L. Pathological process of liver sinusoidal endothelial cells in liver diseases. World J. Gastroenterol. 2017, 23, 7666-7677. [CrossRef]

155. Hösel, M.; Quasdorff, M.; Wiegmann, K.; Webb, D.; Zedler, U.; Broxtermann, M.; Tedjokusumo, R.; Esser, K.; Arzberger, S.; Kirschning, C.J.; et al. Not interferon, but interleukin-6 controls early gene expression in hepatitis B virus infection. Hepatology 2009, 50, 1773-1782. [CrossRef] [PubMed]

156. Van Montfoort, N.; Van Der Aa, E.; Bosch, A.V.D.; Brouwers, H.; Vanwolleghem, T.; Janssen, H.L.A.; Javanbakht, H.; Buschow, S.; Woltman, A.M. Hepatitis B Virus Surface Antigen Activates Myeloid Dendritic Cells via a Soluble CD14-Dependent Mechanism. J. Virol. 2016, 90, 6187-6199. [CrossRef] [PubMed]

157. Fernández-Galindo, D.A.; Sánchez-Ávila, F.; Bobadilla-Morales, L.; Gómez-Quiróz, P.; Bueno-Topete, M.; Armendáriz-Borunda, J.; Sánchez-Orozco, L.V. New amino acid changes in drug resistance sites and HBsAg in hepatitis B virus genotype H. J. Med. Virol. 2015, 87, 985-992. [CrossRef]

158. Luo, Y.; Zhang, L.; Dai, Y.; Hu, Y.; Xu, B.; Zhou, Y.-H. Conservative Evolution of Hepatitis B Virus Precore and Core Gene During Immune Tolerant Phase in Intrafamilial Transmission. Virol. Sin. 2020, 35, 388-397. [CrossRef] [PubMed]

159. Desmond, C.P.; Bartholomeusz, A.; Gaudieri, S.; Revill, P.A.; Lewin, S.R. A systematic review of T-cell epitopes in hepatitis B virus: Identification, genotypic variation and relevance to antiviral therapeutics. Antivir. Ther. 2008, 13, 161-175.

160. Stirk, H.; Thornton, J.; Howard, C. Atopological Model for Hepatitis B Surface Antigen. Intervirology 1992, 33, 148-158. [CrossRef]

161. Wu, C.; Deng, W.; Deng, L.; Cao, L.; Qin, B.; Li, S.; Wang, Y.; Pei, R.; Yang, D.; Lu, M.; et al. Amino Acid Substitutions at Positions 122 and 145 of Hepatitis B Virus Surface Antigen (HBsAg) Determine the Antigenicity and Immunogenicity of HBsAg and InfluenceIn VivoHBsAg Clearance. J. Virol. 2012, 86, 4658-4669. [CrossRef]

162. Theamboonlers, A.; Chongsrisawat, V.; Jantaradsamee, P.; Poovorawan, Y. Variants within the "a" Determinant of HBs Gene in Children and Adolescents with and without Hepatitis B Vaccination as Part of Thailand's Expanded Program on Immunization (EPI). Tohoku J. Exp. Med. 2001, 193, 197-205. [CrossRef]

163. Luongo, M.; Critelli, R.; Grottola, A.; Gitto, S.; Bernabucci, V.; Bevini, M.; Vecchi, C.; Montagnani, G.; Villa, E. Acute hepatitis B caused by a vaccine-escape HBV strain in vaccinated subject: Sequence analysis and therapeutic strategy. J. Clin. Virol. 2015, 62, 89-91. [CrossRef]

164. Carman, W.; Karayiannis, P.; Waters, J.; Thomas, H.; Zanetti, A.; Manzillo, G.; Zuckerman, A. Vaccine-induced escape mutant of hepatitis B virus. Lancet 1990, 336, 325-329. [CrossRef]

165. Howard, C.R.; Allison, L.M. Hepatitis B Surface Antigen Variation and Protective Immunity. Intervirology 1995, 38, 35-40. [CrossRef] [PubMed]

166. Hossain, G.; Ueda, K. Investigation of a Novel Hepatitis B Virus Surface Antigen (HBsAg) Escape Mutant Affecting Immunogenicity. PLoS ONE 2017, 12, e0167871. [CrossRef]

167. Lazarevic, I. Clinical implications of hepatitis B virus mutations: Recent advances. World J. Gastroenterol. 2014, 20, 7653-7664. [CrossRef]

168. Horvat, R.T. Diagnostic and Clinical Relevance of HBV Mutations. Lab. Med. 2011, 42, 488-496. [CrossRef]

169. Yuan, Q.; Ou, S.-H.; Chen, C.-R.; Ge, S.-X.; Pei, B.; Lin, Y.-C.; Ni, H.-Y.; Huang, C.-H.; Yeo, A.E.T.; Shih, J.W.K.; et al. Molecular Characteristics of Occult Hepatitis B Virus from Blood Donors in Southeast China. J. Clin. Microbiol. 2009, 48, 357-362. [CrossRef]

170. Yan, B.; Lv, J.; Feng, Y.; Liu, J.; Jingjing, L.; Xu, A.; Zhang, L. Temporal trend of hepatitis B surface mutations in the postimmunization period: 9 years of surveillance (2005-2013) in eastern China. Sci. Rep. 2017, 7, 1-8. [CrossRef]

171. He, C.; Nomura, F.; Itoga, S.; Isobe, K.; Nakai, T. Prevalence of vaccine-induced escape mutants of hepatitis B virus in the adult population in China: A prospective study in 176 restaurant employees. J. Gastroenterol. Hepatol. 2001, 16, 1373-1377. [CrossRef] 
172. Di Lello, F.A.; Ridruejo, E.; Martínez, A.P.; Pérez, P.S.; Campos, R.H.; Flichman, D.M. Molecular epidemiology of hepatitis B virus mutants associated with vaccine escape, drug resistance and diagnosis failure. J. Viral Hepat. 2018, 26, 552-560. [CrossRef]

173. Mello, F.C.A.; Martel, N.; Gomes, S.A.; Araujo, N.M. Expression of Hepatitis B Virus Surface Antigen Containing Y100C Variant Frequently Detected in Occult HBV Infection. Hepat. Res. Treat. 2011, 2011, 1-4. [CrossRef]

174. Inuzuka, T.; Ueda, Y.; Arasawa, S.; Takeda, H.; Matsumoto, T.; Osaki, Y.; Uemoto, S.; Seno, H.; Marusawa, H. Expansion of viral variants associated with immune escape and impaired virion secretion in patients with HBV reactivation after resolved infection. Sci. Rep. 2018, 8, 18070. [CrossRef]

175. Conway, J.; Cheng, N.; Zlotnick, A.; Stahl, S.; Wingfield, P.; Belnap, D.; Kanngiesser, U.; Noah, M.; Steven, A. Hepatitis B virus capsid: Localization of the putative immunodominant loop (residues 78 to 83) on the capsid surface, and implications for the distinction between c and e-antigens. J. Mol. Biol. 1998, 279, 1111-1121. [CrossRef]

176. Sendi, H.; Mehrab-Mohseni, M.; Shahraz, S.; Norder, H.; Alavian, S.M.; Noorinayer, B.; Zali, M.R.; Pumpens, P.; Bonkovsky, H.L.; Magnius, L.O. CTL escape mutations of core protein are more frequent in strains of HBeAg negative patients with low levels of HBV DNA. J. Clin. Virol. 2009, 46, 259-264. [CrossRef]

177. Ma, Z.; Zhang, E.; Yang, D.; Lu, M. Contribution of Toll-like receptors to the control of hepatitis B virus infection by initiating antiviral innate responses and promoting specific adaptive immune responses. Cell. Mol. Immunol. 2014, 12, $273-282$. [CrossRef] [PubMed]

178. Pei, R.-J.; Chen, X.-W.; Lu, M.-J. Control of hepatitis B virus replication by interferons and Toll-like receptor signaling pathways. World J. Gastroenterol. 2014, 20, 11618-11629. [CrossRef] [PubMed]

179. Wieland, S.; Thimme, R.; Purcell, R.H.; Chisari, F.V. Genomic analysis of the host response to hepatitis B virus infection. Proc. Natl. Acad. Sci. USA 2004, 101, 6669-6674. [CrossRef]

180. Nakagawa, S.-I.; Hirata, Y.; Kameyama, T.; Tokunaga, Y.; Nishito, Y.; Hirabayashi, K.; Yano, J.; Ochiya, T.; Tateno, C.; Tanaka, Y; et al. Targeted Induction of Interferon- $\lambda$ in Humanized Chimeric Mouse Liver Abrogates Hepatotropic Virus Infection. PLoS ONE 2013, 8, e59611. [CrossRef] [PubMed]

181. Brouwer, W.P.; Chan, H.L.Y.; Lampertico, P.; Hou, J.; Tangkijvanich, P.; Reesink, H.W.; Zhang, W.; Mangia, A.; Tanwandee, T.; Montalto, G.; et al. Genome-wide Association Study Identifies Genetic Variants Associated with Early and Sustained Response to (Pegylated) Interferon in Chronic Hepatitis B Patients: The GIANT-B Study. Clin. Infect. Dis. 2019, 69, 1969-1979. [CrossRef]

182. Konerman, M.A.; Lok, A.S. Interferon Treatment for Hepatitis B. Clin. Liver Dis. 2016, 20, 645-665. [CrossRef]

183. Shen, F.; Jieliang, C.; Wang, Y.; Sozzi, V.; Revill, P.A.; Liu, J.; Gao, L.; Yang, G.; Lu, M.; Sutter, K.; et al. Hepatitis B virus sensitivity to interferon- $\alpha$ in hepatocytes is more associated with cellular interferon response than with viral genotype. Hepatology 2018, 67, 1237-1252. [CrossRef]

184. Alcantara, F.F.; Tang, H.; McLachlan, A. Functional characterization of the interferon regulatory element in the enhancer 1 region of the hepatitis B virus genome. Nucleic Acids Res. 2002, 30, 2068-2075. [CrossRef]

185. Lu, J.-J.; Chen, E.-Q.; Yang, J.-H.; Zhou, T.-Y.; Liu, L.; Tang, H. A mutation in the interferon regulatory element of HBV may influence the response of interferon treatment in chronic hepatitis B patients. Virol. J. 2012, 9, 10. [CrossRef] [PubMed]

186. Guo, Y.; Lu, H.; Xu, L.; Idris, N.F.B.; Li, Y.; Hu, J.; Huang, A.; Tu, Z. The response of hepatitis B virus genotype to interferon is associated with a mutation in the interferon-stimulated response element. Medicine 2019, 98, e18442. [CrossRef]

187. Chen, J.; Wu, M.; Wang, F.; Zhang, W.; Wang, W.; Zhang, X.; Zhang, J.; Liu, Y.; Liu, Y.; Feng, Y.; et al. Hepatitis B virus spliced variants are associated with an impaired response to interferon therapy. Sci. Rep. 2015, 5, 16459. [CrossRef]

188. Brook, M.G.; McDonald, J.A.; Karayiannis, P.; Caruso, L.; Forster, G.; Harris, J.R.; Thomas, H.C. Randomised controlled trial of interferon alfa 2A (rbe) (Roferon-A) for the treatment of chronic hepatitis B virus (HBV) infection: Factors that influence response. Gut 1989, 30, 1116-1122. [CrossRef]

189. Perrillo, R. Benefits and risks of interferon therapy for hepatitis B. Hepatology 2009, 49, S103-S111. [CrossRef] [PubMed]

190. Xie, Q.; Shen, H.-C.; Jia, N.-N.; Wang, H.; Lin, L.-Y.; An, B.-Y.; Gui, H.-L.; Guo, S.-M.; Cai, W.; Yu, H.; et al. Patients with chronic hepatitis B infection display deficiency of plasmacytoid dendritic cells with reduced expression of TLR9. Microbes Infect. 2009, 11, 515-523. [CrossRef]

191. Xu, N.; Yao, H.-P.; Lv, G.-C.; Chen, Z. Downregulation of TLR7/9 leads to deficient production of IFN- $\alpha$ from plasmacytoid dendritic cells in chronic hepatitis B. Inflamm. Res. 2012, 61, 997-1004. [CrossRef]

192. Vincent, I.E.; Zannetti, C.; Lucifora, J.; Norder, H.; Protzer, U.; Hainaut, P.; Zoulim, F.; Tommasino, M.; Trepo, C.; Hasan, U.; et al. Hepatitis B Virus Impairs TLR9 Expression and Function in Plasmacytoid Dendritic Cells. PLoS ONE 2011, 6, e26315. [CrossRef]

193. Jiang, M.; Broering, R.; Trippler, M.; Poggenpohl, L.; Fiedler, M.; Gerken, G.; Lu, M.; Schlaak, J.F. Toll-like receptor-mediated immune responses are attenuated in the presence of high levels of hepatitis B virus surface antigen. J. Viral Hepat. 2014, 21, 860-872. [CrossRef] [PubMed]

194. Huang, Y.-W.; Lin, S.-C.; Wei, S.-C.; Hu, J.-T.; Chang, H.-Y.; Huang, S.-H.; Chen, D.-S.; Chen, P.-J.; Hsu, P.-N.; Yang, S.-S.; et al. Reduced Toll-like receptor-3 expression in chronic hepatitis B patients and its restoration by interferon therapy. Antivir. Ther. 2013, 18, 877-884. [CrossRef] [PubMed]

195. Yin, J.W.; Huang, M.P.; Zhong, B. Intrahepatic Toll-Like Receptor 3 in Chronic HBV Infection Subjects: Asymptomatic Carriers, Active Chronic Hepatitis, Cirrhosis, and Hepatocellular Carcinoma. Zahedan J. Res. Med. Sci. 2016, 16. [CrossRef] [PubMed] 
196. Wu, J.; Meng, Z.; Jiang, M.; Pei, R.; Trippler, M.; Broering, R.; Bucchi, A.; Sowa, J.-P.; Dittmer, U.; Yang, D.; et al. Hepatitis B virus suppresses toll-like receptor-mediated innate immune responses in murine parenchymal and nonparenchymal liver cells. Hepatology 2008, 49, 1132-1140. [CrossRef]

197. Xu, Y.; Hu, Y.; Shi, B.; Zhang, X.; Wang, J.; Zhang, Z.; Shen, F.; Zhang, Q.; Sun, S.; Yuan, Z. HBsAg inhibits TLR9-mediated activation and IFN- $\alpha$ production in plasmacytoid dendritic cells. Mol. Immunol. 2009, 46, 2640-2646. [CrossRef]

198. Chen, Z.; Cheng, Y.; Xu, Y.; Liao, J.; Zhang, X.; Hu, Y.; Zhang, Q.; Wang, J.; Zhang, Z.; Shen, F.; et al. Expression profiles and function of Toll-like receptors 2 and 4 in peripheral blood mononuclear cells of chronic hepatitis B patients. Clin. Immunol. 2008, 128, 400-408. [CrossRef]

199. Wang, H.; Ryu, W.-S. Hepatitis B Virus Polymerase Blocks Pattern Recognition Receptor Signaling via Interaction with DDX3: Implications for Immune Evasion. PLoS Pathog. 2010, 6, e1000986. [CrossRef] [PubMed]

200. Liu, Y.; Li, J.; Chen, J.; Li, Y.; Wang, W.; Du, X.; Song, W.; Zhang, W.; Lin, L.; Yuan, Z. Hepatitis B Virus Polymerase Disrupts K63-Linked Ubiquitination of STING to Block Innate Cytosolic DNA-Sensing Pathways. J. Virol. 2014, 89, 2287-2300. [CrossRef]

201. Chen, J.; Wu, M.; Zhang, X.; Zhang, W.; Zhang, Z.; Chen, L.; He, J.; Zheng, Y.; Chen, C.; Wang, F.; et al. Hepatitis B virus polymerase impairs interferon- $\alpha$-induced STA T activation through inhibition of importin- $\alpha 5$ and protein kinase C- $\delta$. Hepatology 2013, 57, 470-482. [CrossRef]

202. Wei, C.; Ni, C.; Song, T.; Liu, Y.; Yang, X.; Zheng, Z.; Jia, Y.; Yuan, Y.; Guan, K.; Xu, Y.; et al. The hepatitis B virus X protein disrupts innate immunity by downregulating mitochondrial antiviral signaling protein. J. Immunol. 2010, 185, 1158-1168. [CrossRef] 